UNIVERSIDADE DE SÃO PAULO

FACULDADE DE ECONOMIA, ADMINISTRAÇÃO E CONTABILIDADE DEPARTAMENTO DE ADMINISTRAÇÃO

PROGRAMA DE PÓS-GRADUAÇÃO EM ADMINISTRAÇÃO

Sofia Batista Ferraz

Consumidores como parceiros: análise do comportamento de cidadania do consumidor em marketing de serviços

Customers as fellows: analyzing customer citizenship behavior in services marketing 
Prof. Dr. Vahan Agopyan

Reitor da Universidade de São Paulo

Prof. Dr. Adalberto Américo Fischmann

Diretor da Faculdade de Economia, Administração e Contabilidade

Prof. Dr. Moacir de Miranda Oliveira Júnior

Chefe do Departamento de Administração

Prof. Dr. Moacir de Miranda Oliveira Júnior

Coordenador do Programa de Pós-Graduação em Administração 
Consumidores como parceiros: análise do comportamento de cidadania do consumidor em marketing de serviços

\title{
Customers as fellows: analyzing customer citizenship behavior in services marketing
}

\begin{abstract}
Dissertation presented to Business Administration Post Graduation Program from Business Administration Department from Economics, Administration and Accounting School of University of São Paulo as a partial requirement for obtaining the title of Philosophy Doctor.
\end{abstract}

Advisor: Prof. Dr. Andres Rodriguez Veloso

\section{Corrected Version}

(original version available at Economics, Administration and Accounting School) 
FICHA CATALOGRÁFICA

Elaborada por Martha Ribeiro Neves de Vasconcellos - CRB-8/5994 Seção de Processamento Técnico do SBD/FEA/USP

Ferraz, Sofia Batista

Customers as fellows: analyzing customer citizenship behavior in services marketing / Sofia Batista Ferraz. - São Paulo, 2018.

$97 \mathrm{p}$.

Tese (Doutorado) -- Universidade de São Paulo, 2018.

Orientador: Andres Rodriguez Veloso

1. Responsabilidade social 2. Valores 3. Comportamento do consumidor 4. Marketing de serviço I. Universidade de São Paulo. Faculdade de Economia, Administração e Contabilidade. II. Título.

$$
\text { CDD }-658.408
$$




\section{ACKOWLEDGMENTS}

This dissertation is a result of collaborative efforts. I would like to thank everybody that, directly or indirectly, encouraged and supported me during these last four years. Thus, I want to adress warm thanks:

To my advisor, Prof. Andres Veloso, for keeping his door opened to me and so many others. As my mentor and friend, I deeply appreciate your encouragement during my time at FEAUSP. I've been learning a lot from you and I plan to keep learning.

To Prof. John Peloza, for giving me the opportunity to study and do research at University of Kentucky. My time at UK changed me as a researcher and as a person. Thank you for your support during this important time.

To Prof. Russ Belk, who welcomed me at York University and, besides immeasurable theoretical and methodological contribution, taught me about kindness and generosity in academia.

To Prof. Diogo Hildebrand, for your help with my thesis during the last months of my program. I hope I can find insightful and collaborative partners like you during my academic journey.

To Prof. Afonso Mazzon, for all your contribution as my professor, researcher, and a person. I hope to keep learning from you too.

To Prof. Kavita Hamza, for your mentoring and friendship. I profoundly admire your empathy and generosity towards your students.

To Prof. Rhonda Radi, for your valuable feedbacks and contributions to my dissertation.

To all my professors and staff from PPGA/FEA-USP, for your essential support during my program. I'm beyond thankful for your help.

To my fellow Master and $\mathrm{PhD}$ colleagues from USP, for your friendship inside and outside our classroom. Specially, I would like to cite Vitor, Camilla, Keysa, Katherine, and Giselle.

Also, a special thanks to FEA-USP Women's Volleyball team for bringing more fun and joy to some stressful days.

To my parents, Tereza and Serafim, for being my references of human beings and for giving me all the emotional and intellectual support I needed since our first day together. I'm immensely grateful for being your daughter.

To my brothers, Guilherme and Gustavo, for the incessant jokes and for being my partners in crime.

To Lucas, for all the love and care. Thank you for always celebrate my achievements as your own. 
To my lovely friends, for understanding my absence but, most importantly, supporting and encouraging me to give my best. Specifically, I want to thank Amanda, Camila, Clara, Jonas, Lorena, Raphaella, Raquel, Renata e Wilson.

Finally, I thank CNPQ, CAPES, Fulbright, and the Government of Canada for the financial support. 
Tecendo a manhã

Um galo sozinho não tece uma manhã: ele precisará sempre de outros galos. De um que apanhe esse grito que ele e o lance a outro; de um outro galo que apanhe o grito de um galo antes e o lance a outro; e de outros galos que com muitos outros galos se cruzem os fios de sol de seus gritos de galo, para que a manhã, desde uma teia tênue, se vá tecendo, entre todos os galos.

E se encorpando em tela, entre todos, se erguendo tenda, onde entrem todos, se entretendendo para todos, no toldo (a manhã) que plana livre de armação. A manhã, toldo de um tecido tão aéreo que, tecido, se eleva por si: luz balão.

(Melo Neto, 1994, p. 219) 



\begin{abstract}
Fellow customers may need opinions about a new gadget, instructions on how to adjust gym equipment or even a lesson on how to self-check-in at the airline kiosk. The possibilities of consumers helping each other vary across services and emphasize its dynamic and interdependent nature. The main purpose of this dissertation threefold. First, we offer theoretical contributions to future studies comprising Customer Citizenship Behavior (CCB). Conducting a systematic review with 92 articles, we suggest new avenues of research regarding theoretical and methodological possibilities. Second, we investigate how customers perceive value by engaging in citizenship behaviors towards the company and other customers. Based on 20 interviews, we draw on Holbrook's typology of values (1999) and Clary et al. (1998) functional theory to suggest contribution regarding the following dimensions: Efficacy or Quality; Social or Esteem; Play or Peace; and Ethics and Spirituality. Third, considering social exchange and self-completion theory, we propose that by endorsing CSR actions and achieving self-definition goals, customers may inhibit posterior displays of $\mathrm{CCB}$ considering that they already obtained satisfaction for helping third parties. Based on 2 experimental studies, we offer support for our proposition with moderation evidence, as well as showing that those participants who perceived a higher entitativity among customers of the companies were more willing to help others in a following situation. Future studies can address the value of CCB by helped customers and employees of the firm. CCB literature is still concentrated on customers who help rather than the ones helped. Other types of citizenship behaviors, such as advocacy, cooperation, and facilitation may comprehend different perceived values and sources of motivation than those explored in this study. Also, regarding our third proposition, studies can evaluate the extent to which those helping behaviors embody self-symbolizing needs and social identifications. Furthermore, the satiation effect of self-completion that we propose in this article happens in a social identity context. Next studies can investigate these effects in other domains, such as self-consistency theory.
\end{abstract}

Keywords: Social Corporate Responsibility, Values, Consumer Behavior, Services Marketing. 


\section{RESUMO}

Consumidores podem precisar de opiniões sobre um novo produto, instruções de como ajustar o equipamento na academia ou até mesmo uma instrução de como fazer o auto check-in na máquina da companhia aérea. As possibilidades de consumidores ajudando uns aos outros variam de acordo com os serviços, enfatizando a sua dinâmica e natureza interdependente. São três os principais propósitos dessa tese. Primeiro, oferecemos contribuições teóricas a futuros estudos no campo do Comportamento Cidadão do Consumidor. Por meio da condução de uma revisão sistemática de 92 artigos, sugerimos novo caminhos para pesquisa teórica e possibilidades metodológicas. Segundo, investigamos como consumidores percebem valor mediante o engajamento em comportamentos cidadãos com a empresa e outros consumidores. Baseado em 20 entrevistas, o estudo está ancorado na tipologia de valores de Holbrook (1999) e teoria funcional de Clary et al. (1998) para sugerir contribuições referentes às seguintes dimensões: Eficácia ou Qualidade; Social ou Estima; Diversão ou Paz; e Ética ou Espiritualidade.Terceiro, considerando Teoria da Troca Social e Teoria da AutoComplementação Simbólica, propõe-se que, ao endossar ações de Responsabilidade Social Corporativa e atingindo objetivos de auto-definição, consumidores podem inibir demonstrações posteriores de CCB, considerando que eles já obtiveram satisfação por ajudar terceiros. Baseado em dois estudos experimentais, oferece-se suporte para a proposição de evidência de moderação, assim como mostra-se que estes participantes perceberam a alta entitatividade entre consumidores das empresas estão mais propensos em ajudar outros em uma situação subsequente. Estudos futuros podem endereçar o valor do CCB relacionado aos consumidores e empregados ajudados. A literatura de CBB ainda é muito concentrada em consumidores que ajudam, ao invés daqueles que são ajudados. Outros tipos de comportamento de cidadania do consumidor, como advocacia, cooperação e facilitação podem compreender diferentes fontes de valor percebidas e fontes de motivação que aquelea comportamentos explorados neste estudo. Ademais, sobre a nossa terceira proposição, estudos podem avaliar a extensão na qual esses comportamentos de ajuda compreendem necessidades de auto-simbolização e identificações sociais. Por fim, o efeito de saciedade da autocomplementação que se propõe nesse artigo acontece em um contexto de identidade social. Estudos futuros podem investigar esse efeito em outros domínios, como a teoria da autoconsistência.

Palavras-chave: Responsabilidade Social Coporativa, Valores, Comportamento do Consumidor, Marketing de serviço. 


\section{LIST OF FIGURES}

Figure 1 - Growth of articles on CCB in journals per year …..................................25

Figure 2 - Network view of dimension Efficacy or Quality .....................................47

Figure 3 - Network view of dimension Social or Esteem...........................................51

Figure 4 - Network view of dimension Play or Peace ...............................................54

Figure 5 - Network view of dimension Ethics or Spirituality …...............................58 



\section{LIST OF TABLES}

Table 1 - Common terms and definitions related to CCB …....................................21

Table 2 - Top 10 journals publishing CCB research ...............................................24

Table 3 - Top 10 papers publishing CCB research ....................................................25

Table 4 - Top publishing authors on CCB literature …............................................26

Table 5 - Number of authors per paper on CCB literature …....................................26

Table 6 - Number of papers with theory testing versus theory building on CCB literature. 27

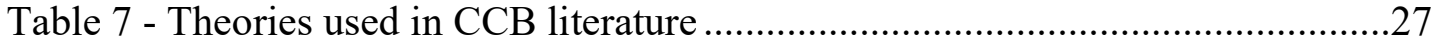

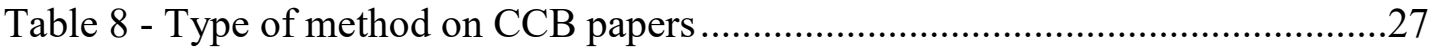

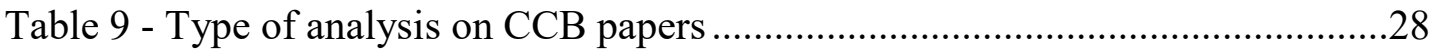

Table 10 - CCB towards company, employees, and customers on the literature .......28

Table 11 - Dimensions of CCB used on CCB papers...............................................29

Table 12 - Adaptation of Holbrook's value framework to CCB ................................37

Table 13 - Adaptation of volunteering functions to $\mathrm{CCB}$.........................................39

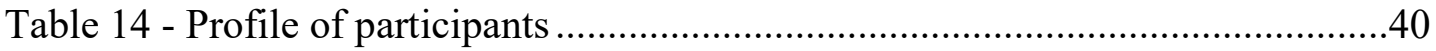

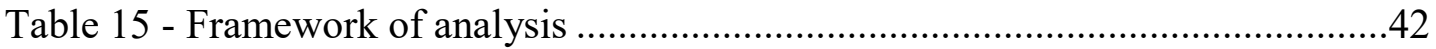

Table 16- Cross tabulation of means (percentage) ...................................................67 


\section{LIST OF ABBREVIATIONS AND ACRONYMS}

ACR Association for Consumer Research

ATM Automatic Teller Machine

BCGA Boys \& Girls Clubs of America

CCB Customer Citizenship Behavior

CFA Confirmatory Factorial Analysis

CIT Critical Incident Technique

CRM Cause-Related Marketing

CSR Corporate Social Responsibility

CVP Customer Voluntary Performance

EFA Exploratory Factorial Analysis

EMAC European Marketing Academy

GLM Generalized Linear Model

OCB Organizational Citizenship Behavior

SD Service-Dominant

SEM Structural Equational Modeling

TEALS Technology Education and Literacy in Schools 


\section{CONTENTS}

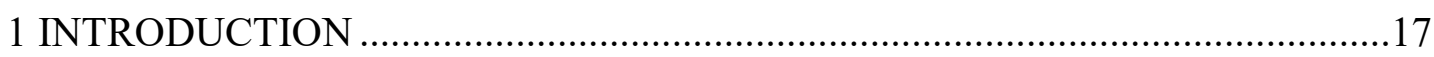

2 CUSTOMER CITIZENSHIP BEHAVIOR: A SYSTEMATIC REVIEW .............19

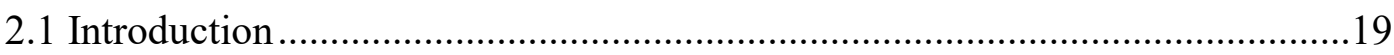

2.2 Customer Citizenship Behavior ............................................................20

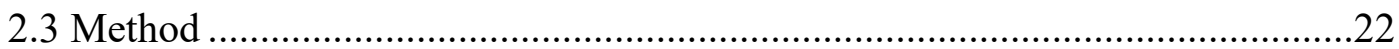

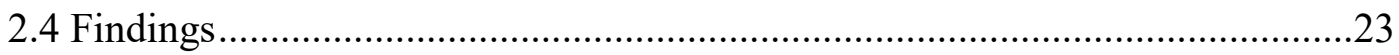

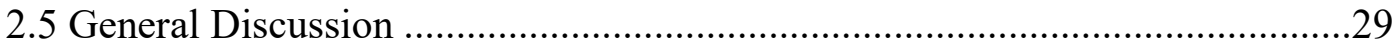

3 “WITH A LITTLE HELP FROM MY CUSTOMERS”: THE PERCEIVED VALUE AND MOTIVATIONS OF CUSTOMER CITIZENSHIP BEHAVIOR .................. 32

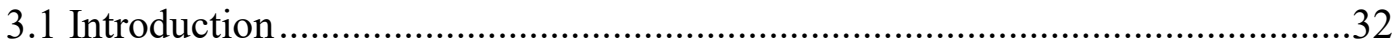

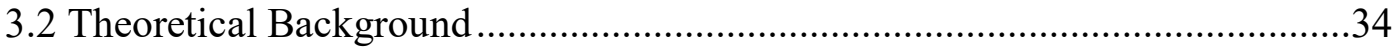

3.2.1 CCB and Holbrook's Typology of Value ................................................34

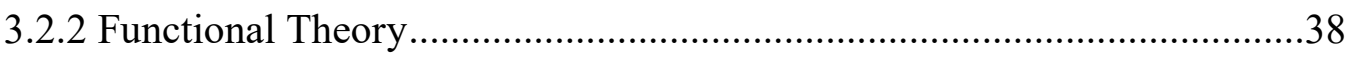

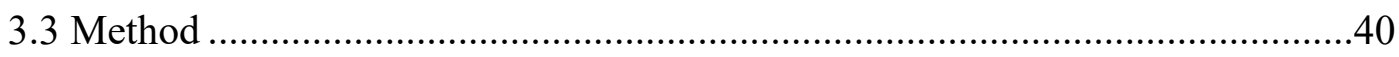

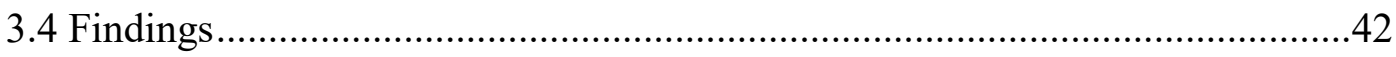

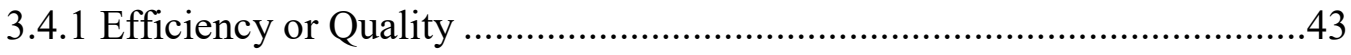

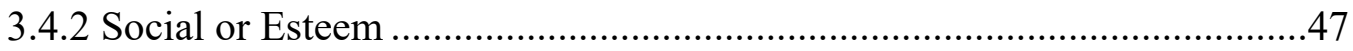

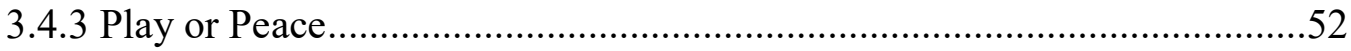

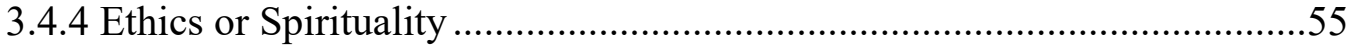

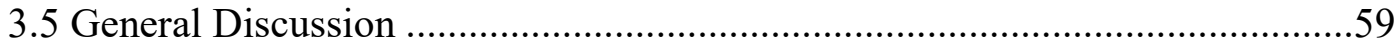

4 “IT'S NOT YOU, IT'S ME”: HOW CORPORATE SOCIAL RESPONSIBILITY DECREASES CUSTOMER CITIZENSHIP BEHAVIOR .................................................63

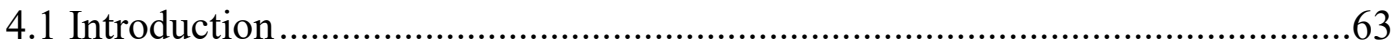

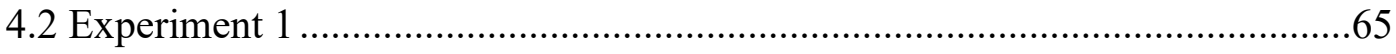


4.2.1 Participants .66

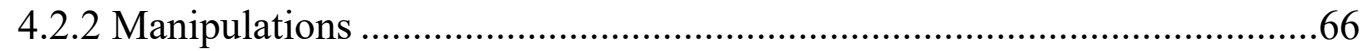

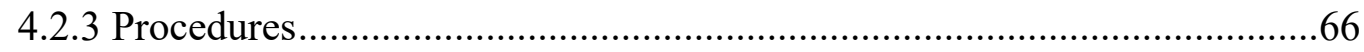

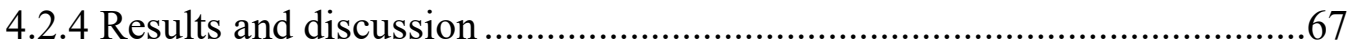

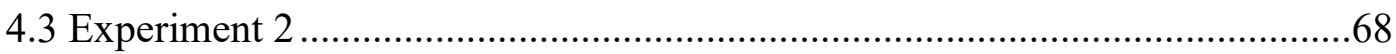

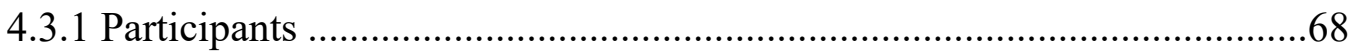

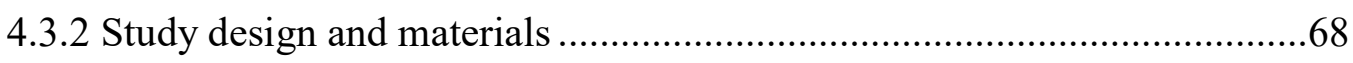

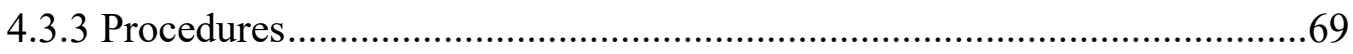

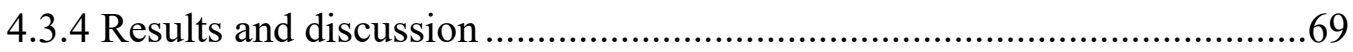

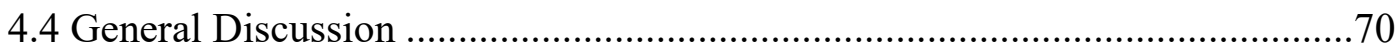

5 CONCLUSION

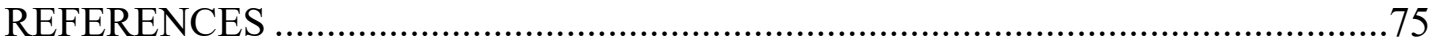

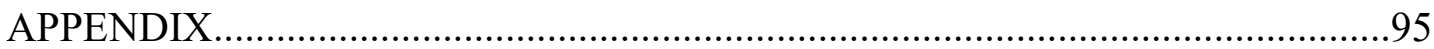

APPENDIX A - MANIPULATIONS OF EXPERIMENT 1 ................................95

APPENDIX B - MANIPULATIONS OF EXPERIMENT 2 ….............................97 


\section{INTRODUCTION}

For a long time, firms would consider "good customers" only those who generate direct revenue to them. The focus on dyadic exchanges between firm and customer changed with the service-dominant (S-D) logic of marketing. Customers represent now active ambassadors of the firm in the service encounter (Kim \& Choi, 2016) who generate social and symbolic capital. Whether teaching another customer how to use the new iPhone or recommending the new movie theater to family and friends, customers are an important asset that helps companies to develop competitive advantage. With investments in technologybased, technology supported services, and customers' empowerment (e.g., Bitner, Brown, \& Meuter, 2000; Cova \& Dalli, 2009), firms have a growing interest in fostering customer voluntary behaviors that traditionally have been operated by employees (Groth, 2005).

These voluntary behaviors, coined customer citizenship behavior (CCB), are known for its discretionary nature that assist the company on successful service delivery (Bettencourt, 1997; Ahearne, Bhattacharya, \& Gruen, 2005). CCB encompasses an enormous variety of voluntary actions (Nguyen et al., 2014), such as helping other customers, recommendations, displays of tolerance, advocacy, and facilitation (Bartikowski \& Wash, 2011; RevillaCamacho, Vega-Vázquez, \& Cossío-Silva 2017).

Further, citizenship behaviors may help on other customer satisfaction, relationship quality, and improve firms'performance revenue (Anaza, 2014). Marketing literature has addressed CCB positive relationships with satisfaction, brand equity, loyalty, corporate reputation, and experience quality (Balaji, 2014; Bartikowski \& Wash, 2011; Burmann, JostBenz, \& Riley, 2009; Lii \& Lee, 2012). Further, has been used as a predictor of customercompany identification (Wang \& Ho, 2017), and employee performance, satisfaction, and commitment (Yi, Nataraajan, \& Gong, 2011).

Despite the consistent and recent developments in the field of CCB, there is still a concentration of methodological and theoretical approaches that we would like to address in this dissertation. Each following chapter refers to an independent study that approach a gap or avenue of research in $\mathrm{CCB}$. Thus, this research aims to analyze $\mathrm{CCB}$ in three ways.

First, in Chapter 2, while the specific focus on customer extra-role behaviors towards the company helps to deepen our understanding of the phenomenon, the wide range of activities and situations prevent us from noticing patterns and relations, besides interfering on the theoretical development of the CCB. The first study aims to analyze existing CCB 
literature, establishing connections, and identifying gaps in different research streams. Thus, we develop a systematic review of $\mathrm{CCB}$ research to provide new directions and ideas to futures studies. This paper is directed to the Journal of Services Marketing due its theoretical and insightful basis. It was already submitted to Encontro de Marketing da Anpad (EMA) 2018 to further contributions.

Second, in Chapter 3, we investigate how customers perceive value by engaging in citizenship behaviors towards the company and other customers. Thus, it aims to analyze what motivates customers to act beyond their roles and how citizenship behaviors are connected to different sources of motivation. We build on consumers' perceived value framework (Holbrook, 1994, 1999) and functional theory (Clary et al., 1998) to formally analyze these values and motivations. Despite the early call from Bettencourt (1997) and increasing interest in $\mathrm{CCB}$ in recent years, there is a scarcity of studies addressing individual differences that influence these behaviors. Understanding factors, motivations, and circumstances that lead to relational exchanges are imperative to develop competitive advantage from customer (inter)actions. We plan to submit this paper to European Marketing Academy (EMAC) Conference 2019 and publish it in Journal of Service Research.

Third, in Chapter 4, we propose, counterintuitively, that by endorsing CSR actions and achieving self-definition goals, customers may inhibit posterior displays of CCB (i.e., helping fellow customers) considering that they already obtained satisfaction for helping third parties. We adopt social identity theory (e.g., Tajfel \& Turner, 1979; Belk, 1988; Lam, Ahearne, Hu \& Schillewaert, 2010) and self-completion lens (Wicklund \& Gollwitzer, 1981) to address our research goal. This paper was submitted to ACR Conference 2018 and we will also submit it to the Journal of Consumer Psychology (JCP) in a Research Report format (4000 words) due to its insightful and counterintuitive proposal.

Chapter five comprises final considerations and offer a bridge to connect all three studies. 


\section{CUSTOMER CITIZENSHIP BEHAVIOR: A SYSTEMATIC REVIEW}

\subsection{Introduction}

Customers play a relevant role on companies' activities, acting as social capital, cocreators, "partial employees," and feedback providers regarding service delivery (Bettencourt, 1997; Bowen, Schneider, \& Kim, 2000; Curth, Uhrich, \& Benkenstein, 2014; Groth, 2005). They are actively interacting with different actors in the service encounter, including other customers (Kim \& Choi, 2016). During decades, the focus of researchers was employees' roles and extra-role behaviors that could affect the effectiveness of organizational functioning (Organ, 1988), and consequently impact consumer behaviors (Heskett, Sasser, \& Schlesinger, 1997; Nguyen, Groth, Walsh, \& Hennig-Thurau, 2014). The focus on dyadic exchanges between firm and customer changed with the service-dominant (S-D) logic of marketing. Besides, the consolidation of a relationship-oriented perspective emphasized customers and their relationships as sources of competitive advantage (Gouthier \& Schmid, 2003). The increasing relevance of customers in the service delivery fomented both academics and practitioners to understand interactional and situational dynamics that permeate customer participation in value creation (e.g., Choi \& Lotz, 2016; Yi \& Gong, 2013).

Recently, studies have recognized the importance of customer citizenship behaviors (CCB), which are "voluntary and discretionary behaviors that are not required for the successful production and/or delivery of the service but that, in the aggregate, help the service organization overall" (Groth, 2005, p. 11), on firms' performance and revenue (Anaza, 2014; Yi \& Gong, 2008). The essential difference between coproduction behaviors and CCB is that the last one encompasses an enormous variety of voluntary actions (Nguyen et al., 2014). Examples of CCB towards the firm include giving feedbacks, advocacy, flexibility, participation in firms' activities, and policing other stakeholders.

While the specific focus on customer extra-role behaviors towards the company helps to deepen our understanding of the phenomenon, the wide range of activities and situations prevent us from noticing patterns and relations, besides interfering on the theoretical development of the field. This research aims to analyze existing CCB literature, establishing connections, and identifying gaps in different research streams. Thus, we develop a systematic review of CCB research to provide new directions and ideas to futures studies.

Our contributions to the marketing and CCB field are twofold. First, we are the first study to offer a panoramic and integrative view encompassing $\mathrm{CCB}$ literature. Since 
Bettencourt's (1997) seminal article, in which he coined the term Customer Voluntary Performance (CVP), we witnessed the emergence of a substantial volume of collaborations. Second, we address the claim of authors for more unified literature that may congregate findings and bridge already existent theoretical contributions. This process will also reveal unexplored research possibilities and possible inconsistencies in the field.

In the next section, we review CCB theory and prior research. Methods are presented in the sequence, evidencing the procedure used with the systematic review. In the following, we discuss the findings and, lastly, the general discussion.

\subsection{Customer Citizenship Behavior}

Theoretically based on organizational citizenship behavior (OCB), the consideration of customers as "partial employees" and "good soldiers" of the firm was triggered by the necessity to transcend productive resources to beyond conventional business models (Bettencourt, 1997; Organ, 1988). The increasing participation of customers in services encounters, appropriating new functions and behaviors in consonance with the value proposition of the firm, moved Groth (2005) towards the conception of CCB. With Bettencourt (1997) and Groth (2005) contributions, other conceptualizations and dimensions emerged from a joint effort of Ahearne, Bhattacharya, and Gruen (2005) and Bove, Pervan, Beatty, and Shiu (2009) (see Table 1). Interestingly, in the last five years, we observed a flourishing enthusiasm regarding CCB (e.g., Kim \& Choi, 2016; Xie, Poon, \& Zhang, 2017; Revilla-Camacho, Vega-Vázquez, \& Cossío-Silva, 2015; Yi \& Gong, 2013).

Due to the development of studies on CCB field in the last twenty years, there were significant efforts towards the development of measurements and scales. Groth (2005) proposed a scale comprising three factors of CCB (i.e., recommendations, providing feedback, and helping other customers). With variations to for-profit and non-profit firms, Johnson and Rapp (2010) also elaborated a comprehensive scale for customer helping (comprising expanding behaviors, supporting behaviors, forgiving behaviors, increasing quantity, competitive information, responding to research, and rising price), while Yi and Gong (2013) measured $\mathrm{CCB}$ and customer participation as two dimensions of value co-creation. Choi and Lotz (2016) suggested a CCB motivations scale with 12 items, composed by selfenhancement, desire to support the service provider, the perception of the provider's past performance, and personal principles. 
Table 1 - Common terms and definitions related to CCB

\begin{tabular}{|c|c|c|c|}
\hline Concept & Definition & Dimensions & Source \\
\hline $\begin{array}{l}\text { Customer } \\
\text { Voluntary } \\
\text { Performance } \\
\text { (CVP) }\end{array}$ & $\begin{array}{l}\text { Helpful, discretionary } \\
\text { behaviors of customers } \\
\text { that support the ability of } \\
\text { the firm to deliver service } \\
\text { quality. }\end{array}$ & $\begin{array}{l}\text { Customer suggestions for } \\
\text { service improvement; } \\
\text { cooperation and } \\
\text { conscientiousness during the } \\
\text { service encounter; and positive } \\
\text { word-of-mouth and } \\
\text { recommendations. }\end{array}$ & $\begin{array}{l}\text { Bettencourt } \\
\text { (1997) }\end{array}$ \\
\hline $\begin{array}{l}\text { Customer } \\
\text { Citizenship } \\
\text { Behavior } \\
\text { (CCB) }\end{array}$ & $\begin{array}{l}\text { Voluntary and } \\
\text { discretionary behaviors } \\
\text { that are not required for } \\
\text { the successful production } \\
\text { and delivery of the service } \\
\text { but that, in the aggregate, } \\
\text { help the service } \\
\text { organization overall. }\end{array}$ & $\begin{array}{l}\text { Making recommendations; } \\
\text { helping other customers; } \\
\text { providing feedback to the } \\
\text { organization. }\end{array}$ & Groth (2005) \\
\hline $\begin{array}{l}\text { Customer } \\
\text { extra-role } \\
\text { behavior }\end{array}$ & $\begin{array}{l}\text { Extra-role behaviors (e.g., } \\
\text { citizenship) desired by the } \\
\text { company that are not } \\
\text { required for successful } \\
\text { service delivery. }\end{array}$ & $\begin{array}{l}\text { Making recommendations; } \\
\text { advocacy; volunteering; } \\
\text { cooperation. }\end{array}$ & $\begin{array}{l}\text { Ahearne, } \\
\text { Bhattacharya, } \\
\text { and Gruen } \\
(2005)\end{array}$ \\
\hline $\begin{array}{l}\text { Customer } \\
\text { Organizational } \\
\text { Citizenship } \\
\text { Behavior } \\
\text { (customer } \\
\text { OCB) }\end{array}$ & $\begin{array}{l}\text { Voluntary behaviors } \\
\text { outside of the customer's } \\
\text { required role for service } \\
\text { delivery, which aim to } \\
\text { provide help and } \\
\text { assistance, and are } \\
\text { conducive to effective } \\
\text { organizational functioning. }\end{array}$ & $\begin{array}{l}\text { Positive word-of-mouth; } \\
\text { displays of relationship } \\
\text { affiliation; participation in } \\
\text { firm's activities; benevolent } \\
\text { acts of service facilitation; } \\
\text { Flexibility; Suggestions for } \\
\text { service improvements; Voice; } \\
\text { Policing other customers. }\end{array}$ & $\begin{array}{l}\text { Bove et al. } \\
\text { (2009) }\end{array}$ \\
\hline
\end{tabular}

The extant literature in CCB has focused on its antecedents. To cite some examples, customer satisfaction, loyalty, and commitment (Anaza, 2014; Anaza \& Zhao, 2013; Bartikowski \& Walsh, 2011; Bettencourt, 1997; Eisingerich, Auh, \& Merlo, 2014; Groth, 2005), brand relationship quality (Jung, Yoo, \& Arnold, 2017; Thompson, Kim, \& Smith, 2016), relationship and customer experience quality (Balaji, 2014; Kim \& Choi, 2016), ethical corporate identity and customer-based corporate reputation (Bartikowski \& Walsh, 2011; Karaosmanoglu, Altininge, \& Isiksal, 2016), social-emotional and instrumental support from other customers (Rosenbaum \& Massiah, 2007; Yi, Gong, \& Lee, 2013), identification and commitment to fellow customers (Curth, Ulrich, \& Benkenstein, 2014; Johnson, Massiah, \& Allan, 2013), personal loyalty and commitment to the service worker (Bove et al., 2009), and personal characteristics like empathy, altruism, and enhancement (Anaza, 2014; Oyedele \& Simpson, 2011). 
Another stream of research has approached CCB as a predictor of satisfaction, trust, and attitudinal loyalty (Revilla-Camacho, Vega-Vázquez, \& Cossío-Silva, 2017), customercompany identification (Wang \& Ho, 2017), and employee performance, satisfaction, and commitment (Yi, Nataraajan, \& Gong, 2011). Despite the consistent and recent developments, there is still a concentration of methodological and theoretical approaches. Also, CCB has been assuming different terms in the literature what may undermine the diffusion of the construct. Most importantly, for being a relatively new field, the breadth of expansion and fresh ideas is latent. In the next section, we explore more about the systematic review and following steps.

\subsection{Method}

The broad array of customers' discretionary behavior and its potential value in services settings indicate both relevance and dispersion within the marketing field. In this vein, there is a growing interest in understanding how consumers can help companies to improve their performance (e.g., Gilde et al., 2011; Jung, Yoo, \& Arnold, 2017; Rosenbaum \& Massiah, 2007; Thompson, Kim, \& Smith, 2015) but still a necessity to examine and systematize the nature, dimensions, and motivations of their behaviors (Anaza, 2014; Kim \& Choi, 2016; Johnson \& Rapp, 2010; Revilla-Camacho, Vega-Vázquez, \& Cossío-Silva, 2017). A solution to fragmented interdisciplinary literature is the development of systematic reviews which aims a conceptual consolidation about a topic (Rousseau et al., 2008). The process includes a transparent and reproducible scheme that encompasses the search and critical appraisal of studies (Crossan \& Apaydin, 2010). We followed a procedure based on three steps: planning, execution, and reporting (Tranfield et al., 2003).

At the planning phase, we established our objectives and defined our search criteria (i.e., databases, type of articles, period, and keywords.) To obtain a broad view of how CCB impacts the value creation for stakeholders, we searched within the academic literature focusing on four databases: PsychINFO, which offers access to nearly 2,500 journals in the behavioral and social sciences; EBSCO Business Complete, which have around 7,767 peerreviewed journals and magazines in full text; SocIndex, which covers sociology and related disciplines with more than 620 active journals; and ProQuest, which includes over 3,000 business and management publications.

Given the plurality of terms related to CCB, the keywords used for the search through titles, abstracts, and keywords fields were: customer citizenship behavior, customer 
organizational citizenship behavior, customer voluntary participating behavior, customer extra-role behavior, customer voluntary performance, customer-to-customer interaction, client citizenship behavior, customer-to-customer influence, extra-role citizenship behavior, fellow customers, consumer-to-consumer helping, customer engagement behavior, intercustomer social support, and customer helping customer. The list of keywords reflects diffuse literature on $\mathrm{CCB}$ that assumed a broad range of terms and definitions.

During the execution phase, we established five stages to analyze our data. Thus, we began with (1) identifying our selection criteria previously established; (2) grouping publications based on theories, methodologies, and CCB activities (pattern-matching); (3) selecting a consideration set; (4) categorizing results; and (5) synthesizing our findings (Crossan \& Apaydin, 2010). Synthesizing, the first three steps consisted of organizing the data, while the following two steps referred to analysis and compilation of results.

The initial list encompassed a total of 61 articles. A subsequent search on Google Scholar and Emerald Journals, with a portfolio of near 300 journals, increased the number to 85. Since our main objective is to analyze how researchers have been exploring $\mathrm{CCB}$, we only included empirical studies. The search had no restriction by date and was focused solely on full-text peer-reviewed articles. Finally, we complemented our data with a search of references lists of the collected articles to find missed studies. An additional of 7 studies expanded our total to 92 papers. The modest volume of articles may reflect the stage of development of the theory since the term CCB was only coined by Groth (2005).

After the compilation of the final article list, one independent coder was used to provide reliability. The primary focus on coding was the details of theoretical lenses used (e.g., social exchange theory and social identity theory), CCB dimensions (e.g., helping, recommendation, tolerance, advocacy, and cooperation), and towards who the citizenship behavior (i.e., company, other customers and/or employees) was performed. Other coded material comprehended methodological approaches, such as types of method, analysis, and sample.

\subsection{Findings}

Analyzing the sources of papers in the field of CCB (see Table 2), we verify that most parts of the papers was published in Journal of Business Research (11\%), Journal of Services Marketing (8\%), Journal of Strategic Research (5\%), Psychology \& Marketing (5\%), and Journal of Consumer Marketing (4\%). In the top 10 journals, we perceived a tendency for 
publications of journals with a broader range of topics, such as Journal of Business Research, Journal of Strategic Marketing, and Psychology \& Marketing Journal, but also in journals directed to services marketing (i.e., Journal of Services Marketing, The Services Industries Journal, and Journal of Service Research).

Table 2 - Top 10 journals publishing CCB research

\begin{tabular}{clcc}
\hline Rank & \multicolumn{1}{c}{ Source titles } & No. papers & $\begin{array}{c}\text { \% of most } \\
\text { cited }\end{array}$ \\
\hline $\mathbf{1}$ & Journal of Business Research & 10 & $11 \%$ \\
$\mathbf{2}$ & Journal of Services Marketing & 7 & $8 \%$ \\
$\mathbf{3}$ & Journal of Strategic Marketing & 5 & $5 \%$ \\
$\mathbf{4}$ & Psychology \& Marketing & 5 & $5 \%$ \\
$\mathbf{5}$ & Journal of Consumer Marketing & 4 & $4 \%$ \\
$\mathbf{6}$ & Tourism Management & 3 & $3 \%$ \\
$\mathbf{7}$ & The Services Industries Journal & 3 & $3 \%$ \\
$\mathbf{8}$ & Sustainability & 3 & $3 \%$ \\
$\mathbf{9}$ & Journal of Service Research & 2 & $2 \%$ \\
$\mathbf{1 0}$ & Journal of the Academy of Marketing Science & 2 & $2 \%$ \\
\hline
\end{tabular}

Along the same lines, we looked for papers per year to verify the growth, decline, or stagnation of publications (see Figure 1). Since the pioneering work of Bettencourt (1997), we noticed a peak of articles in 2010 and 2011 (5 and 7, respectively). This evident growth was boosted by the guest editorial of Journal of Strategic Marketing about "The engagement of customer beyond their roles" (Pervan \& Bove, 2011). The special issue comprised a total of 3 papers with our search criteria. With the same tendency, beginning from 2012 and particular attention to $2014 / 2015$ until 2017 , we notice a significant increase of publications regarding $\mathrm{CCB}$ research. Change of paradigms and new trends of production and consumption, such as co-creation and self-service machines, may have raised the interest of researchers in studying new dynamics in services encounters (e.g., Yi \& Gong, 2013; Yi \& Kim 2016). 
Figure 1 - Growth of articles on CCB in journals per year

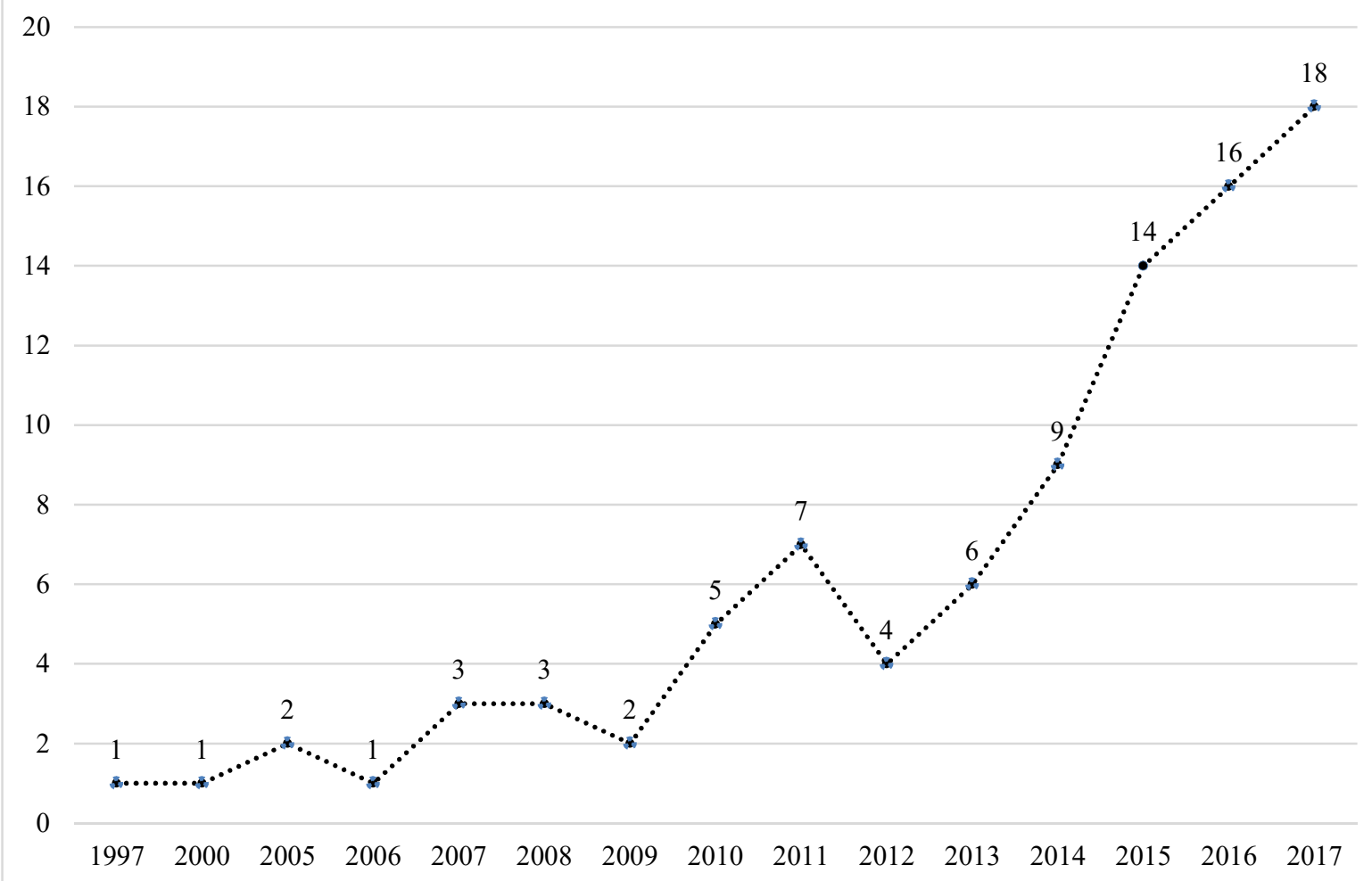

Bettencourt (1997) was the pioneer in investigating customer's extra-role behavior.

Due to its pioneer position on the field and his contributions to the build of CCB, he has 1504 citations $(23 \%)$. Based on Table 3, we can notice the consistent difference between him and Ahearne, Bhattacharya \& Gruen (2005), who have 884 citations (13\%). Not surprisingly, studies that proposed new scales had a substantial number of citations in this ranking: Groth (2005), Yi \& Gong (2013), and Bove et al. (2009) had 477, 380, and 306 citations, respectively.

Table 3 - Top 10 papers publishing CCB research

\begin{tabular}{clcc}
\hline Rank & \multicolumn{1}{c}{ Authors } & $\begin{array}{c}\text { No. of } \\
\text { citations }\end{array}$ & \% of citations \\
\hline $\mathbf{1}$ & Bettencourt (1997) & 1504 & $23 \%$ \\
$\mathbf{2}$ & Ahearne, Bhattacharya \& Gruen (2005) & 884 & $13 \%$ \\
$\mathbf{3}$ & Groth (2005) & 477 & $7 \%$ \\
$\mathbf{4}$ & Yi \& Gong (2013) & 380 & $6 \%$ \\
$\mathbf{5}$ & Bove, Pervan, Beatty \& Shiu (2009) & 306 & $5 \%$ \\
$\mathbf{6}$ & Rosenbaum \& Massiah (2007) & 282 & $4 \%$ \\
$\mathbf{7}$ & Lii \& Lee (2012) & 280 & $4 \%$ \\
$\mathbf{8}$ & Yi, Nataraajan, and Gong (2011) & 197 & $3 \%$ \\
$\mathbf{9}$ & Huang and Hsu (2010) & 189 & $3 \%$ \\
$\mathbf{1 0}$ & Wu (2007) & 188 & $3 \%$ \\
\hline
\end{tabular}


We have also verified the most publishing authors on CCB (Table 4). Youjae Yi is the most productive author, with a total of 7 papers. Cathy Hsu and Taeshik Gong have six articles each, while Seo Kim and Jue Huang have 5. An interesting aspect is the number of partnerships between authors and co-authors reflected on the top publishing 5. For example, Yi and Gong have developed fours studies together. Hsu and Huang worked in 2 publications in the same scope.

Table 4 - Top publishing authors on CCB literature

\begin{tabular}{clc}
\hline Rank & \multicolumn{1}{c}{ Authors } & No. papers \\
\hline $\mathbf{1}$ & Youjae Yi & 7 \\
$\mathbf{2}$ & Cathy H. C. Hsu and Taeshik Gong & 6 \\
$\mathbf{3}$ & Seo Yeoung Kim and Jue Huang & 5 \\
$\mathbf{4}$ & $\begin{array}{l}\text { Nai-Chia Chen and Hefu Liu } \\
\mathbf{5}\end{array}$ & $\begin{array}{l}\text { Liliana L. Bove, Kaung-Hwa Chen, Yong Zhang, Lu Chen, } \\
\text { Jaewon Joo, Todd J. Arnold, Tung-Ching Lin, Ching-Wei Ho, } \\
\text { and Simon J. Pervan }\end{array}$ \\
& & 3 \\
\hline
\end{tabular}

Complementarily, we observed the tendency of papers with more than one author (see Table 2.4). The higher frequency of papers with $2(28 \%), 3(40 \%)$, and $4(18 \%)$ authors is contrasting with $1(11 \%)$ and $5(2 \%)$. West (2007) affirmed that single-authored papers have been losing space to papers with two and three authors. Malhora (1996) corroborate when declares that there is a rise in the number of authors per article. Marketing scholars seem to have been embracing partnerships in the last year for reasons concerning innovation and new sources of inspiration (looking for interdisciplinary approaches), but also for the high demand for publications (Nel et. al, 2011).

Table 5 - Number of authors per paper on CCB literature

\begin{tabular}{ccc}
\hline No. of authors & No. of papers & \% of papers \\
\hline $\mathbf{1}$ & 10 & $11 \%$ \\
$\mathbf{2}$ & 26 & $28 \%$ \\
$\mathbf{3}$ & 37 & $40 \%$ \\
$\mathbf{4}$ & 17 & $18 \%$ \\
$\mathbf{5}$ & 2 & $2 \%$ \\
\hline Total & 92 & $100 \%$ \\
\hline
\end{tabular}

Thus, besides collective efforts from authors to teamwork with other scholars, we observe that most studies are worried about testing theories $(89 \%)$ rather than building new 
ones (11\%), according to Table 6. Despite de advances in the number of publications, there is still a latent necessity for expanding the field of study. Our findings dialogue with Crossan and Apaydin (2010) since they found that this is a recurrent issue in the field of Business, Finance Economics, and Management. In their case, applied to the sphere of innovation, theory building represented only $6 \%$ of papers.

Table 6 - Number of papers with theory testing versus theory building on CCB literature

\begin{tabular}{ccc}
\hline & No. of papers & \% of papers \\
\hline Theory Testing & 82 & $89 \%$ \\
Theory Building & 10 & $11 \%$ \\
\hline Total & 92 & $100 \%$ \\
\hline
\end{tabular}

Social exchange theory (20\%) represents the most accepted theory when accessing CCB (Table 7). Often related to it, we noticed Social identity theory (7\%) and Role Theory (3\%) as still underused lenses. Agency theory, self-congruency theory, empathy theory, motives based, and others appeared in a reduced proportion. The symbol $\mathrm{n} / \mathrm{a}$ represents the lack of theory positioning found in the papers, while one study could present more than one theory (the reason why $\mathrm{n}=123$ ).

Table 7 - Theories used in CCB literature

\begin{tabular}{lcc}
\hline \multicolumn{1}{c}{ Theories } & No. of papers & \% of papers \\
\hline Social Exchange Theory & 24 & $20 \%$ \\
Social Identity Theory & 8 & $7 \%$ \\
Role Theory & 4 & $3 \%$ \\
Others & 58 & $47 \%$ \\
$\mathrm{n} / \mathrm{a}$ & 29 & $24 \%$ \\
\hline Total & 123 & $100 \%$ \\
\hline
\end{tabular}

As expected after results regarding theory testing, the survey is the dominant method (74\%), followed by experiments (9\%), interview/survey (8\%), interview (4\%), and participant observation (2\%). Case study, secondary data, and focus group comprehend a total of 3 articles (1 each). Quantitative methods are predominant, including 7 cases when there are both interview and survey (see Table 8).

Table 8 - Type of method on CCB papers

\begin{tabular}{lccc}
\hline & Method & No. of papers & \%of papers \\
\hline Survey & 68 & $74 \%$
\end{tabular}




\begin{tabular}{lcc} 
Experiments & 8 & $9 \%$ \\
Interview/Survey & 7 & $8 \%$ \\
Interview & 4 & $4 \%$ \\
Participant observation & 2 & $2 \%$ \\
Case Study & 1 & $1 \%$ \\
Secondary Data & 1 & $1 \%$ \\
Focus Group & 1 & $1 \%$ \\
\hline Total & 92 & $100 \%$ \\
\hline
\end{tabular}

We also investigated the type of analysis performed on CCB papers (Table 9). Most of the articles used Confirmatory Factorial Analysis and Structural Equation Modeling (CFA/SEM), representing the dominant $61 \%$ (56) of papers published in the field. The use of ANOVA/Manova represented 9\% (8) of articles, while Content Analysis comprehended 8\% (7). The results are aligned with methods previously reported. Other methods, such as Regression Analysis and EFA also appeared on the most used type of analysis.

Table 9 - Type of analysis on CCB papers

\begin{tabular}{lcc}
\hline Analysis & No. of papers & \% of papers \\
\hline CFA/SEM & 56 & $61 \%$ \\
Anova/Manova & 8 & $9 \%$ \\
Content Analysis & 7 & $8 \%$ \\
Regression Analysis & 5 & $5 \%$ \\
EFA/SEM & 2 & $2 \%$ \\
Others & 14 & $15 \%$ \\
\hline Total & 92 & $100 \%$ \\
\hline
\end{tabular}

Focusing on the theoretical stream of this study, we found that $\mathrm{CCB}$ is usually performed towards the company (32\%). Company and customers (30\%) are also widely used when performing citizenship behaviors (Table 10). With a less representative frequency, we observed that company, employees, and customers represent the target of $18 \%$ of these behaviors. Customers only (15\%) still compose a significant part of CCB dimensions. Company and employees had minor participation (4\%).

Table 10 - CCB towards company, employees, and customers on the literature

\begin{tabular}{lcc}
\hline \multicolumn{1}{c}{ CCB towards } & No. of papers & \% of papers \\
\hline Company & 29 & $32 \%$ \\
Company and customers & 28 & $30 \%$ \\
Company, employees, and customers & 17 & $18 \%$ \\
Customers & 14 & $15 \%$
\end{tabular}




\begin{tabular}{lcc} 
Company and employees & 4 & $4 \%$ \\
\hline Total & 92 & $100 \%$ \\
\hline
\end{tabular}

The most significant share of CCB dimensions was captured by feedback (20\%), followed by helping other customers (19\%) and recommendation (12\%). As expected, these three dimensions are initially suggested by Groth (2005) and replicated in other studies. Further, feedback and helping other customers agree with the considerable number of studies comprising CCB towards the company and towards the company and customers (see Table 11). Also, other citizenship behaviors, such as facilitation, advocacy, word-of-mouth (intrinsically connect to recommendations, but with its literature), cooperation, participation, and tolerance also appeared in our studies. The number of papers exceeds 92 because studies used more than one citizenship behavior.

Table 11 - Dimensions of CCB used on CCB papers

\begin{tabular}{clcc}
\hline Rank & \multicolumn{1}{c}{ Dimensions } & No. of papers & \% of papers \\
\hline 1 & Feedback & 40 & $20 \%$ \\
2 & Helping & 38 & $19 \%$ \\
3 & Recommendation & 23 & $12 \%$ \\
4 & Facilitation & 13 & $7 \%$ \\
5 & Advocacy & 11 & $6 \%$ \\
6 & Word-of-mouth & 9 & $5 \%$ \\
7 & Cooperation & 9 & $5 \%$ \\
8 & Participation & 8 & $4 \%$ \\
9 & Tolerance & 6 & $3 \%$ \\
10 & Others & 40 & $20 \%$ \\
\hline
\end{tabular}

We covered aspects related to a more general scope of $\mathrm{CCB}$, in which we provided information about top publishing journals in the field, CCB papers per year, number of authors per paper, and most cited papers and authors. Then, we advanced to a more specific sphere to approach the dominance of theory testing papers in $\mathrm{CCB}$, and type of methods and analysis most used in the studies. Finally, we presented evidence regarding CCB towards company, customers, and employees. We also delineated the most frequent CCB behaviors used in these studies. Next, we discuss our findings and offer new directions of research.

\subsection{General Discussion}

We analyzed existing CCB studies, building connections among them, and identifying gaps that future researchers could address. In this sense, we discuss here some possibilities of 
studies that encompasses the theoretical and methodological field of citizenship behaviors.

The literature on CCB has been growing exponentially in the last five years. The increasing number of studies also reflects the relevance of the subject to academics and practitioners. Social Exchange Theory has been the dominant research stream in most of the studies, followed by the less expressive lenses of Social Identity Theory and Role Theory. Extant theories are still understudied and represent significant sources of contributions (e.g., empathy, self-concept, and self-congruency theories). Most importantly, a considerable amount of papers doesn't position their contributions to the theory, what may interfere in the building theory process.

A total of fourteen papers account for more than $80 \%$ of citations. Most of them, deal with the effect of $\mathrm{CCB}$ on customers' evaluation of the firm and satisfaction regarding the service delivery. Quantitative papers would provide interesting input to build and develop meta-analysis on the influence of $\mathrm{CCB}$ on satisfaction and commitment to the company, for example.

Research has focused predominantly on quantitative methods and analysis, when feelings, emotions, and motivations involved in such activities may require a more interpretative approach. Other methods may (or even combining methods) provide new perspectives about the same phenomenon.

Regarding the focus of CCB towards company and customers, we observed a latent necessity to approach this interaction: studies addressing how do employees feel about customers taking on their roles? How is this managed in service settings? In which contexts would employees feel supported my fellow customers? Another opportunity for research is the difference between traditional services (e.g., restaurants) versus pop-up services (e.g., music festivals), where there is no connection between employee and customers. Moving to another perspective of $\mathrm{CCB}$, few papers offered insights regarding the recipient of citizenship behaviors. How do they feel about it and do they reciprocate the favor to the firm or other customers? How does culture influence the propensity to engage in CCB? Issues related to self-construal (interdependent versus dependent) or personal values (see Schwartz \& Bilsky, 1984), may play an essential role in engaging on CCB.

Additional efforts may be direct to the integration of negative aspects of $\mathrm{CCB}$ into general servicescape theory. Service theory tells us that services can be a play, with actors, and scripts. How do we deal with "bad actors" that are not aware of their scripts? How do we nudge customers into accepting guidance in doing their "acting"?

Feedback, recommendations, and helping other customers are predominant in the 
literature. How could we explore different types of CCB? Recommendations may have a different underlying mechanism than tolerance, for example. Understanding these divergences may help to build ideas to promote cooperation in the service encounter, besides promoting competitive advantage to the firm. 


\section{3 "WITH A LITTLE HELP FROM MY CUSTOMERS": THE PERCEIVED VALUE AND MOTIVATIONS OF CUSTOMER CITIZENSHIP BEHAVIOR}

\subsection{Introduction}

Under the aegis of goods-centered dominant logic, customers were something to be caught and acted on: in line with eventual suggestions from English terminology, companies would "segment," "penetrate", and "promote to" the market to attract customers (Vargo \& Lusch, 2004). Now, moving towards an active perspective, customers have multiples avenues open to them to help companies. They are expected to participate in brand communities (Adjei, Noble, \& Noble, 2010; Zaglia, 2013), volunteer (Cova, Pace, \& Skalen, 2015; Giebelhausen, Chun, Cronin Jr, \& Hult, 2016), donate time and money (e.g., Bhattacharya \& Sen 2004; Lichtenstein, Drumwright, \& Braid, 2004; Liu \& Aaker, 2008), foster new product success (Joshi \& Sharma, 2004), and co-create services (e.g., Dong, Evans, \& Zou 2008; Edvarsson, Tronvoll, \& Gruber, 2011; Roggeveen, Tsiros, \& Grewal, 2012). Customers participation went beyond transactions to become collaborators involved in the entire service experience.

As temporary employees and human resources of the organization, they can support the company with unsolicited, extra-roles behaviors, including helping other customers, being tolerant, facilitating services, giving recommendations, and feedbacks (Bartikowski \& Wash, 2011; Groth, 2005; Revilla-Camacho, Vega-Vázquez, \& Cossío-Silva 2017). According to Groth (2005), these discretionary performances are defined as customer citizenship behavior (CCB) and are "not required for the successful production and delivery of the service but that, in the aggregate, help the service organization overall" (p. 11). Marketing literature has addressed $\mathrm{CCB}$ positive relationships with satisfaction, brand equity, loyalty, corporate reputation, customer-company identification, and experience quality (Balaji, 2014; Bartikowski \& Wash, 2011; Burmann, Jost-Benz, \& Riley, 2009; Lii \& Lee, 2012). The focus of prior studies has been on the development of measurements and scales (e.g., Choi \& Lotz, 2016; Groth, 2005; Johnson \& Rapp, 2010; Yi \& Gong, 2013), in addition to processes involving antecedents and consequences of CCB (e.g., Bove, Pervan, Beatty, \& Shiu, 2009; Karaosmanoglu, Altinigne, \& Isiksal, 2016; Nguyen, Groth, Walsh, \& Hennig-Thurau, 2014). Despite the early call from Bettencourt (1997) and increasing interest in CCB in recent years, there is a scarcity of studies addressing individual differences that influence these behaviors. Understanding factors, motivations, and circumstances that lead to relational exchanges are 
imperative to develop competitive advantage from customer (inter)actions.

The current study investigates how customers perceive value by engaging in citizenship behaviors towards the company and other customers. Further, it aims to analyze what motivates customers to act beyond their roles and how citizenship behaviors are connected to different sources of motivation. In light of this discussion, we build on consumers' perceived value framework and functional theory to formally analyze these values and motivations.

Drawing on Holbrook's typology (Holbrook, 1994, 1996, 1999), we examine in detail the perceived value of the customer in engaging in CCB. The four dimensions (self-oriented vs. other-oriented; intrinsic vs. extrinsic) suggested in his integrative framework offer a theoretical lens to analyze the potential types of value that may be present on the experiential value of customers. Due to its dynamic nature, Holbrook's multidimensional model has constantly been revisited in the marketing literature for the last decades (e.g., Gallarza \& Saura, 2006; Leroi-Werelds, Streukens, Brady, \& Swinnen, 2014; Mathwick, Malhotra, \& Rigdon, 2002; Peloza \& Shang, 2011; Sánchez-Fernández \& Iniesta-Bonillo, 2007).

We also adopt the functional theory approach (Finkelstein \& Brannick, 2007; Oyedele \& Simpson, 2011) to explore underlying motives for customers engage on volunteer, extrarole behaviors (i.e., CCB). The core premise of functional analysis is recognizing that acts of volunteerism that seem to be so superficially identic may be related with considerably "different underlying motivational processes [...] influencing critical events associated with the initiation and maintenance of voluntary helping behavior" (Clary et al., 1998, p. 1517). In the context of this research, we focus on five motivational functions: (1) values function, demonstrating altruistic and humanitarian motives; (2) social function, concerning social rewards and punishments; (3) understanding function, based on the chance to practice abilities and knowledge to enhance self-development; (4) protective function, regulating guilt and protecting ego; and (5) enhancement function, satisfying self-esteem (Clary, Snyder, \& Stukas, 1996; Oyedele \& Simpson, 2011). The functional framework proposed by Clary et al. (1996) will supplement Holbrook's dimensions to obtain a comprehensive view of customers' perceived values regarding citizenship behaviors.

Contributions to marketing theory are threefold. First, we offer an analysis of customers' values on performing CCB. To the best of our knowledge, no article has focused until now on comprehending customer value and its dimensions concerning these voluntary behaviors. Besides, we expand Holbrook's typology by adapting and applying it to the realm of customers' helping behaviors. Second, we use the functionalist theory lens (Clary et al., 
1996) to add a new perspective to the dimensions of values. Oyedele and Simpson (2011) worked with four motivational functions to understand CCB. We include a fifth function (i.e., "Understanding") based on Clary et al. (1996) suggestions to better explain the phenomena. Third, studies have approached CCB towards the firms, employees and other customers as the same construct or even separately in clusters (CCB-F, CCB-E, and CCB-C, respectively). In this study, we unravel citizenship behaviors analyzing their nature based on their resources, actors, and processes. Helping other customers, giving feedbacks, providing recommendations, and demonstrating tolerance (e.g., Choi \& Lotz, 2016; Groth, 2005; Xie, Poon, \& Zhang, 2017) are substantially distinct behaviors since each one reflect specific values and sources of motivation. These have relevant implications for developing customeroriented strategies to manage customer behaviors properly (Balaji, 2014) and consequently foster firm recognition and reputation (Nguyen et al., 2014).

This study is organized as follows: the next section provides previous research on CCB, Holbrook's typology of perceived value, and functional theory. Next, we detail data collection and analysis procedures involving Critical Incident Technique (CIT). After discussing the results, we offer final discussion with theoretical and managerial considerations.

\subsection{Theoretical Background}

We articulate the literature regarding citizenship behaviors, Holbrook's typology of values, and functional theory to introduce our framework of analysis. Prior studies and conceptual articulations will support the steps to investigate how customers are stimulated to act beyond their roles.

\subsubsection{CCB and Holbrook's Typology of Value}

Studies encompassing citizenship behaviors have focused on employees for years (Groth, 2005; Podsakoff, Whiting, Podsakoff, \& Blume, 2009), failing to address a customer perspective. Theoretically originated on organizational citizenship behavior (OCB), CCB reinforces the extra-role of customers as partners and collaborators of the firm (Organ, 1988). CCB differentiates from customer co-production due to its discretionary initiatives beyond the requirements to provide service delivery (Nguyen et al., 2014). In this sense, citizenship behaviors are more diversified and likely to alternate among customers. They can perform these behaviors as currency to give support to the organization at their discretion (Bove et al., 
2009). The broad range of CCB applications also reflects the diversity of terms and operationalization promoted by different authors: customer voluntary performance (CVP), customer extra-role behavior, and organizational citizenship behavior (customer OCB) are examples of terminologies commonly found in the literature (Ahearne, Bhattacharya, \& Gruen, 2005; Bettencourt, 1997; Bove et al., 2009; Groth 2005). Besides, each conceptualization usually encompasses activities such as helping other customers (Black, Vincent, \& Skinner, 2014; Johnson, Massiah, \& Allan, 2013; Jung, Yoo, \& Arnold, 2017; Parker \& Ward, 2000; Yi \& Gong, 2013); recommendations (Anaza \& Zhao, 2013; Balaji, 2014); feedback (Bartikowski \& Walsh, 2011; Choi \& Lotz, 2016; Groth, 2005); tolerance (Revilla-Camacho, Vega-Vázquez, \& Cossío-Silva, 2015); facilitation (Anaza, 2014; Kim \& Choi, 2016; Lii \& Lee, 2012); cooperation (Bettencourt, 1997; Oyedele \& Simpson, 2011; Yi, Gong, \& Lee, 2013; Yi, Nataraajan, \& Gong, 2011); and advocacy (Garma \& Bove, 2011; Rosenbaum \& Martin, 2012).

CCB literature has concentrated in the domain of social exchange theory (e.g., Anaza, 2014; Anaza \& Zhao, 2013; Xie, Poon, \& Zhang, 2017) and social identity theory (e.g., Johnson, Massiah, \& Allan, 2013; Lii \& Lee, 2012). Most importantly, researchers have focused on how extra-role behaviors can generate beneficial outcomes to firms based on favorable interactions with customers (Gilde, Pace, Pervan, \& Strong, 2011). According to the seminal work of Groth (2005), the concept of CCB suggests that benefits from these behaviors are directed towards the firm and, also, indirectly by targeting employees and other customers. In this sense, Yi and Gong (2008) found that the effect of customer satisfaction on $\mathrm{CCB}$ is stronger when there are higher communication frequency and relationship age. Lii and Lee (2012) observed the influence of customer-company identification and brand attitude on in-role and extra-role behaviors. Balaji (2014) discussed of relationship quality and strength as antecedents, while Anaza and Zhao (2013) and Eisingerich, Auh, and Merlo (2014) focused on the effects that customer satisfaction and loyalty exert on CCB. Jung, Yoo, and Arnold (2017) recently demonstrated the positive outcomes of a strong service climate on CCB and OCB. Despite the favorable view of CCB, Garma and Bove (2011) noted that some helping behaviors could harm organizations: for example, when a customer help employees by informing them about opening positions in other firms, or when a customer tells another customer about a better product of a competing brand or store.

Thus, the view that extra-role behaviors are favorable to the company is predominant (e.g., Bettencourt, 1997; Bove et al., 2009; Yi, Nataraajan, \& Gong, 2009) despite the abstractedness of how these behaviors are valued and intrinsically motivated in the customer 
perspective. Although citizenship behaviors create a propitious social context for the enjoyment of the service experience (Lengnick-Hall, Claycomb, \& Inks, 2000), the linear perspective that they are triggered by positive factors of the company (regarding the salient notion of reciprocity derived from social exchange theory) and produce favorable outcomes can be misleading. For example, a customer may be tolerant in a service encounter because he doesn't have a better alternative to solve the problem. Along similar lines, he can help a fellow customer due to the absence of employees to do the job. In both situations, citizenship behaviors are motivated by different reasons and do not correspond necessarily to a favorable outcome in the medium or long term.

Interestingly, the perceived value on helping the company, employees or other customers can have different sources of value that will shape citizenship behaviors. The search for understanding this background becomes crucial for the development and framing of strategies that prioritize customers and their interactions with the company and fellow customers (e.g., customer co-creation). Addressing this assertion, we suggest Holbrook's typology of customer's perceived value (Holbrook, 1994, 1996, 1999) to investigate "compresent" nature and types of values - that tend to occur together in various degrees regarding dynamics of $\mathrm{CCB}$.

Holbrook's framework is based on the axiology of values (Lewis, 1946; Perry, 1954) and refers to an "interactive relativistic preference experience" (Holbrook, 1999, p.5) of some object (e.g., a service, a social cause, a political candidate) by a subject (usually a consumer or another consumer). The framework consists of three dichotomies (Holbrook, 1994, 1999; Sánchez-Fernández \& Iniesta-Bonillo, 2007). The first one encapsulates extrinsic versus intrinsic value, where extrinsic refers to the functionality and instrumentality of the object to attain a purpose (the cut of a knife or the hole of a drilling machine) and intrinsic to the appreciation of the experience as an end in itself, being considered a self-sufficient and selfjustified activity (for example, the gratification feeling of endorsing a social cause or the enjoyment of a trip to the mountains).

The second dichotomy englobes self-oriented versus other-oriented value. Selforiented is connected to the aspect in which customers are concerned with their own sake or the effect that it will have on themselves (a car that helps to get faster and more comfortable to work or the new turntable that provides a joyful audio experience). Contrarily, otheroriented value goes beyond the self and consider the extent of how the experience will affect others, how others react to it, and how others value it (e.g., to purchase of a dress to impress friends and family or to adopt organic food to help next generations). 
The multidimensional construct of perceived value proposed by Holbrook (1994, 1999 ) is a set of several interrelated aspects and dimensions that have been referenced in different domains (e.g., Leroi-Werelds, Streukens, Brady, \& Swinnen, 2014; Steenkamp \& Geyskens, 2006; Zainuddin, Russell-Bennett, \& Previte, 2013). Combining two of the suggested dichotomies (self-oriented versus other-oriented and extrinsic versus intrinsic value), we adapted the typology of consumer value to a $2 \times 2$ cross-tabulation with four different dimensions to $\mathrm{CCB}$ context, as shown in Table 12 with salient examples in each quadrant. To analyze citizenship behavior and the helping provided to firms and other customers, we assume a personal, interactional, and situational perspective consistent with Holbrook's typology of values (1999).

Table 12 - Adaptation of Holbrook's value framework to CCB

\begin{tabular}{|c|c|c|}
\hline & Extrinsic & Intrinsic \\
\hline \multirow[b]{2}{*}{ Self-oriented } & 1. Efficiency or Excellence & 3. Play \\
\hline & $\begin{array}{l}\text { "Helping other customers makes my } \\
\text { life easier" }\end{array}$ & $\begin{array}{l}\text { "Being tolerant helps to prevent } \\
\text { further stress and keep my peace" }\end{array}$ \\
\hline & 2. Status or Esteem & 4. Ethics or Spirituality \\
\hline Other-oriented & $\begin{array}{l}\text { "Making a recommendation is a way } \\
\text { to represent to the company that I'm a } \\
\text { good customer" }\end{array}$ & $\begin{array}{l}\text { "Giving feedback is a way to } \\
\text { contribute to a fairer environment" }\end{array}$ \\
\hline
\end{tabular}

Source: Adapted from Holbrook (1999).

In quadrant 1 of Table 12, citizenship behaviors are useful at contributing to the service-related benefits from a product or service. In the case of helping other customers, the self-oriented value is transparent: for example, "helping other customers makes life easier" by speeding up the service. In quadrant 2, moving to other-oriented perspective, the perception of value from $\mathrm{CCB}$ is focused on others and translated into the status/esteem embed on being helpful. Thus, "making a recommendation is a way to represent to the company that I'm a good customer" or even "a way to represent to family and friends that I'm a well-informed person." The focus on others than self is the crucial difference from quadrant 1. Quadrant 3 represents the inner appreciation of performing a citizenship behavior, such as when "being tolerant helps to prevent further stress and keep me mentally healthy." Finally, in quadrant 4, the value of CCB is perceived from contributing to a common and public good. For instance, when a customer considers that "giving feedback is a way to contribute to a fairer environment". According to our analysis, the four types of perceived value may be found in different dimensions of CCB (i.e., helping other customers, feedback, recommendation, and 
tolerance). To broaden our understanding of values and motivations, we also include contributions from functional theory.

\subsubsection{Functional Theory}

Themes related to functionalism have long being concentrated on actions of individuals towards personal and social goals (Pervin, 2015). Functional analysis stems from reasons and meanings, plans and motives that determine and produce psychological phenomena (Snyder, 1992). These functions are used in a wide range of individual and social behaviors and are highly compatible with a diversity of domains, such as basic human needs, attitude theory, and axiology of values (e.g., Maslow, 1968; Katz, 1960). A central assumption from functionalist approach is that different people can generate the same behavior with distinct functions in mind (Snyder, 1993); that is, customer performing similar citizenship behaviors on the surface may be serving diverse sources of motivations. Take the case of helping a fellow customer. Some customers may help others with the automatic teller machine (ATM) due to an instrumental motive like to accelerate the line to use the device. Some people may do it to avoid the feeling of guilt for not helping a person who is apparently in need. For others, a good reason would be related to an ego-enhancing function in which they would feel wise, competent, and powerful for being able to perform a behavior better than others. Still, some customers may help to affirm values of benevolence and solidarity. In the same vein of Holbrook's compresence of values, customers may have more than one function to serve and need to fulfill.

Clary et al. (1998) and Clary and Snyder (1999) worked on the realm of functional theory by approaching volunteerism motivations. With the concern of including self and egorelated functions, they suggested a total of six functions that reflect a variety of attitudes towards helping people and general prosocial activities. The functional perspective incites the examination of diverse self and other-oriented motivations that sustain the behavior of helping. Besides the wide range of motives, the interactionist and situational lenses in which motivations match opportunities of the environment may disclose relevant consequences (Clary et al., 1998; Oyedele \& Simpson, 2011). In this sense, their functional framework embrace functions of values; understanding; social; career; protective; and enhancement. Due to our specific scope of $\mathrm{CCB}$, we discarded the career function since its benefits are careeroriented and reflect another phenomenon. We focused on the other five functions after careful consideration, as evidenced in Table 13. 
In Table 13, we specify the five motivational functions provided by CCB. Additionally, we connect these functions to each one of Holbrook's types of values to offer a comprehensive analysis of how and why customers engage in citizenship behaviors (Holbrook, 1999). While social and values functions are already contemplated in Holbrook's proposition (see third and fourth quadrant, respectively), we include understanding, protective, and enhancement functions. Although excluded from previous studies (e.g., Oyedele \& Simpson, 2011), understanding function represent a vital instrument to apprehend skills, resources, and processes that may be used during or after the service encounter (for example, learn how to operate an updated software or practice the underdeveloped competence of speaking in public). This function is oriented to the self and extrinsically apprehended with interactions between customer and environment. Protective and enhancement functions are both associated with the ego and characterized by intrinsic and self-oriented dimensions. While protective encompasses a defensive concern to protect the self from negative aspects, enhancement involves the canalization of positive efforts towards ego development (Clary et al., 1998; Katz, 1960).

Table 13 - Adaptation of volunteering functions to CCB.

\begin{tabular}{|c|c|c|}
\hline Function & Definition & $\begin{array}{l}\text { Holbrook's types of } \\
\text { values }\end{array}$ \\
\hline Understanding & $\begin{array}{l}\text { Customers are seeking to learn more about the } \\
\text { service or exercise skills often unused. }\end{array}$ & $\begin{array}{l}1 \\
\text { Extrinsic } \\
\text { Self-oriented }\end{array}$ \\
\hline Social & $\begin{array}{l}\text { Helping allows customers to gain social recognition } \\
\text { or strengthen social relationships (related to social } \\
\text { rewards and punishments). }\end{array}$ & $\begin{array}{l}2 \\
\text { Extrinsic } \\
\text { Other-oriented }\end{array}$ \\
\hline Protective & $\begin{array}{l}\text { Helping is used to reduce negative feelings (e.g., } \\
\text { guilt) and address personal issues like escape from } \\
\text { one's own problems. }\end{array}$ & $\begin{array}{l}\mathbf{3} \\
\text { Intrinsic }\end{array}$ \\
\hline Enhancement & $\begin{array}{l}\text { Helping allows someone to grow and develop } \\
\text { psychologically (e.g., self-esteem). }\end{array}$ & Self-oriented \\
\hline Values & $\begin{array}{l}\text { Customers help to act on relevant values like altruism } \\
\text { and humanitarianism. }\end{array}$ & $\begin{array}{l}4 \\
\text { Intrinsic } \\
\text { Other-oriented }\end{array}$ \\
\hline
\end{tabular}

Source: Adapted from Clary and Snyder (1999) and Holbrook (1999).

The identification of motivational foundations is an appropriate resource to investigate the factors that guide CCB and unfolding dynamics. In this study, we propose an analysis of how customers perceive value and feel motivated towards performing citizenship behaviors. 
Next, we approach critical incident technique (CIT) and delineate methodological procedures used to understand the phenomena.

\subsection{Method}

We adopted the critical incident technique (CIT), originally proposed by Flanagan (1954), to investigate CCB motivations and following events. The technique "consists of a set of procedures for collecting direct observations of human behavior in such a way as to facilitate their potential usefulness in solving practical problems" (Flanagan, 1954, p. 327). CIT is characterized as a qualitative interview process which allows a systematic, resourceful, open-ended data collection and analysis (Breunig \& Christoffersen, 2016). When customers explain a phenomenon connected to their life background, they can disclose personal thoughts, emotions, and evaluations that accompanied their experience (Gardner, 1985; Parasuraman, Berry, \& Zeithaml, 1991). The technique has been widely used in the services marketing literature (Gremler, 2004), including sources of satisfaction and dissatisfaction (e.g., Bitner, Booms, \& Tetreault, 1990; Grove \& Fisk, 1997; Meuter, Ostrom, Roundtree, \& Bitner, 2000), service failure or recovery (e.g., Hoffman, Kelley, \& Rotalsky, 2003; Lewis \& Spyrakopoulos, 2001), reasons for switching providers (Keaveney, 1995), customer outrage and delight (Verma, 2003), misbehaviors (Harris \& Daunt, 2013) and defective co-creation behaviors (Greer, 2015).

An incident is an observable act entire on itself that allows inferences and conclusions about the individual's activity (Bitner, Booms, \& Tetreault, 1990; Flanagan, 1954). According to Keatinge (2002), critical incidents relate to representative or meaningful behaviors or circumstances. In the case of the present study, the critical incident had to meet the subsequent criteria: 1) comprise a customer-to-customer or customer-company interaction; 2) involve helping other customers (strangers), recommendations, feedbacks or displays of tolerance (CCB dimensions); and 3) must specify context and circumstances with satisfactory details to be apprehended by the researcher.

The data for this study were collected over 3-months period. The author conducted two waves of interviews. Notes from interviews supplemented the transcriptions. Our sample reflected product and service customers with heterogeneous demographic profiles: age, occupation, education, and family status (see Table 14).

Table 14 - Profile of participants

\begin{tabular}{llll}
\hline Pseudonym & Age & Occupation & Family Status \\
\hline
\end{tabular}




\begin{tabular}{llll}
\hline Alex & 47 & Psychologist & Divorced \\
Anne & 31 & Architect & Married \\
Carl & 30 & Consultant & Single \\
Carrie & 29 & Graduate student & Single \\
Charlotte & 34 & Health technician & Married, with kids \\
Corinne & 31 & Communications analyst & Single \\
David & 52 & Consultant & Divorced, with kids \\
Gabriel & 27 & Engineer & Single \\
Jerry & 42 & Graduate student & Married, with kids \\
Jake & 27 & Business analyst & Single \\
John & 45 & Physiotherapist & Married, with kids \\
Kate & 39 & College professor & Single \\
Larry & 29 & Business manager & Single \\
Loren & 31 & Police officer & Married \\
Matt & 28 & Lawyer & Single \\
Rebecca & 26 & Logistics manager & Single \\
Rory & 28 & Lawyer & Single \\
Rose & 28 & Architect & Married \\
Tina & 52 & College professor & Married, with kids \\
Tory & 46 & Secretary & Married, with kids \\
\hline
\end{tabular}

Primarily, information-rich participants were convoked from personal networks, then followed by snowball sampling technique. We required new respondents until reaching theoretical saturation and information repetition, wherein no additional insights were gained (Greer, 2015). The total recording time was 554.5 minutes, with interviews ranging from 20 to 44 minutes. Also, a total of 171 pages of transcriptions.

Semi-structured interviews began with an open-ended question, requiring the interviewees to "think of a time when, as a customer, you helped or gave support to another customer in a service encounter." They were free to select the service to evoke a more detailed description (Meuter et al., 2000). If respondents were having difficulty in accessing the incident, the interviewer would suggest a predefined list of 15 service settings commonly used by customers and tested in previous studies to help recollection. The services include bank, gym, restaurant, bar, concert, doctor/physician's office, hospital, hair salon/barber shop, hotel, amusement park, movie theater, air/train/bus, and sports game (Zhang, Beatty, \& Mothersbaugh 2010). We proceed with the same operationalization to comprise the other dimensions of CCB included in this study (i.e., making recommendations, giving feedbacks, and being tolerant).

Following questions encouraged respondents to contribute with more details:

- Which circumstances lead up to this situation?

- Why is this experience memorable to you? 
- Did the episode affect your experience as a customer? How?

- What was the outcome of your action?

- Did you feel benefited or harmed anyhow? Why?

- How did you feel helping in this situation?

- How did the service provider (e.g.., employees, processes, physical structure, etc.) influence your action?

After data collection and transcription, we thoroughly analyzed the respondents' experiences: vertically, to identify data categories and sub-categories; and horizontally to group and summarize (Grove \& Fisk, 1997; Breunig \& Christoffersen, 2016). According to Miles and Huberman (1994), coding process requires descriptive, interpretive, and pattern coding. The iterative process and constant comparison among stories were particularly useful to notice these emerging patterns. The author and an independent judge manually coded the incidents and discussed discrepancies until reaching on an agreement. In a second moment, we also used ATLAS.ti 8.1.2 (qualitative software) (Butterfield et al., 2005). The double coding evidenced inter-judge reliability of over 80 percent.

Addressing Gremler's claim (2004) to have a more narrative approach, our analysis brought insights also by looking for contextualization and explanation from participants. In addition to cognitive aspects, emotions connected to the incidents helped to analyze the incidents. We also offer Network views to each discussed, from ATLAS.ti, to provide a better comprehension of perceived values and its dynamics.

\subsection{Findings}

Our analysis of CCB perceived values and motivations suggests specific ways in which our participants interact with companies, employees, and other customers. As we looked at the data stemmed from critical incidents, sub-categories emerged to compose our analysis. To simplify our exposition, we structure our framework building on Holbrook's typology of values and Clary et al. (1998) additional functions (see Table 15). However, as we discuss our framework, we explain how these categories are parts or interactive and situational processes, in which values from different dimensions are intrinsically connected to attend various sources of motivations.

Table 15 - Framework of analysis

\begin{tabular}{ccc}
\hline Dimensions & Categories & \multicolumn{1}{c}{ Subcategories } \\
\hline Self-oriented & 1. Efficiency or Quality & Convenience
\end{tabular}


Extrinsic

$\begin{array}{lll}\text { Other-oriented } & \text { 2. Social or Esteem } & \begin{array}{l}\text { Networking } \\ \text { Reputation }\end{array} \\ & & \begin{array}{l}\text { Comforting } \\ \text { Enhancement }\end{array} \\ \text { Self-oriented } & \text { 3. Play or Peace } & \begin{array}{l}\text { Happiness } \\ \text { Peace of mind } \\ \text { Protective }\end{array}\end{array}$

Intrinsic
Other-oriented
4. Ethics or Spirituality

Money

Time

Excellency

Performance

Understanding

Networking

Comforting

Enhancemen

Altruism

Benevolence

Empathy

Morality/justice

Sacredness

Our discussion also contemplates four distinct citizenship behaviors to offer a more comprehensive picture of CCB. We looked closely to intertwined patterns that support our discussion. The subsequent analysis follows the scheme of the detailed categories. First, we approach subcategories related to Efficiency or Quality. Next, we present results derived from Social or Esteem and Play or Peace, respectively. Lastly, we develop our discussion on Ethics or Spirituality.

\subsubsection{Efficiency or Quality}

Extrinsic and self-oriented dimensions reveal an instrumental facet on engaging in citizenship behaviors. In this case, the perceived value is related to a "tangible" extrinsic reward to oneself or to prevent the loss of a valued resource (Barbuto, 2001). Customers will perform the activity to receive a benefit from it, as a means to an end, rather than for the inherent pleasure of the experience itself (Vallerand, 1997). With a focus on the self and egoist motives, $\mathrm{CCB}$ is a way to promote favorable outcomes to their own reality. One of the subcategories explored in the Efficacy or Quality quadrant is Convenience, in which customers esteem an effortless perspective that doesn't demand significant energy (valued benefit) from customers. We observed "Convenience" values in most of the cases regarding citizenship behaviors of tolerance. One of the study's participants, Gabriel, reports:

Weekly, my internet connection goes down when I'm here, and it's something that really bothers me because my free time is basically playing online games or watching $T V$ series. So, it's something that affects me personally. It's their duty to work this out, 
but the inconvenience of switching my provider [sigh]... The idea of going after another provider, then canceling mine, adding the new one, new installation fees, these stuff... all these factors make me accept the service as it is, and not how it should be.

Gabriel informed that he's new in town and doesn't go out a lot. Still, even with frequent quality oscillations of his internet provider, his primary source of entertainment, he prefers to accept the service "as it is" due to the tiring steps that he would have to take to switch providers. This activity would require him some effort, besides the expenditure of resources such as time and money. Interestingly, the literature on CCB approach displays of tolerance as beneficial to the organization (e.g., Groth, 2005, Choi \& Lotz, 2016), but it also raises an issue regarding in which extent it can harm the relationship between customercompany in the medium or long-term. Gabriel also states that if he moves to another place, he will avoid a contract with the same provider "at all costs."

Another extrinsic value directed to the self is connected to the financial sub-dimension of Money. As a tangible resource that is recurrent in consumption routines and a symbol of security, power, and freedom (Matthews, 1991; Hansen, Kutznet, \& Wanke, 2012), money is one of the most identified sub-dimensions concerning to Efficacy or Quality, along with convenience and quality. The anticipation of losing or saving a financial asset may elicit a more severe action of customers (Zhou, Vohs, \& Baumeister, 2009). In the case of David, his experience of inadvertently spend money triggered a feedback to the company. He says:

She [bank manager], to achieve her sales goal, registered two private pension plans in my account. I requested a chargeback and she asked me if she could do it only in the next month. Since I needed the money and knew what was happening there, I gave a feedback to the Ombudsman of the bank.

Additionally, David expresses that he "knew what was happening there" in allusion to the deviance of conduct of his manager and working as a monitor of the firm. He lists the need for the money and for exerting justice as causes that propitiated the feedback to her superior. Justice is another value of our framework and is associated with other-oriented intrinsic motives. These motivations corroborate with Holbrook (1999) explanation of the compresence of values, in which values may coexist to justify the same outcome.

Efficacy or Quality dimension also highlights Time as valued by customers. Since people can't retrieve time, there is a stream of research that advocates that losing time may be more painful than losing money (e.g., Leclerc, Schmitt, \& Dubé, 1995). Also, Mogilner and Aaker (2009) explore the idea of time as a critical construct to understand the relationship with a consumption experience. The abstract and ambiguous essence of time reinforces the 
fragility of dealing with it as an instrumental dimension. The following incident of Tina nicely illustrates the emergence of time as our sub-dimension:

I told the saleswoman: "Look, the line to the cashier is too long. The same girl who is operating the cashier is also taking off clothing labels." Got it? And she was also packing the clothes. The line was getting longer and longer. So, I told the saleswoman: "Look, don't you think that someone else could help her with this task?"

In the attempt to get control of her time, Tina draws attention to the overwhelmed cashier and suggests some help. Her feedback had the same intention of the helping provided by John:

I helped him to help me because he was already using the ATM a long time ago. He must have repeated the operation three or four times, that is, he was delaying everybody. And when I gave him the information, he finished faster.

John's report that he "helped him to help me" stands out helping other customers as a means to an end (i.e., get faster to the ATM). In his situation, the end is extrinsically functional and self-focused accordant with the first quadrant of Holbrook (1994, 1999). The next perceived value is Excellency, inherently linked to Efficiency or Quality. Rose told us that she usually goes to an Italian restaurant and appreciate the quality of the food a lot, despite the long time that takes to her order to arrive. In her discourse about tolerance, she keeps repeating how the delay of the food bothers her, but she is always mending that the food is "very good", as a licensing that the restaurant achieved. With her words,

[We are still clients] because of the quality of the food. So, the food is very good there. The problem is not even the attendance of the staff... the problem is the delay. I think the problem is in the kitchen. But, still... the food is very good.

The tangible perception of quality serves as motivation to being tolerant. Still concerning Excellency, Rebecca reflects on the motives of her recommendation to a close friend. Unintentionally, she offers a parallel between the service expected and the service received (Grönroos, 1984; Taylor \& Baker, 1994) when approaches the excellence of her gym. Besides the technical outcome (what customer gets), the functional result (how the customer receives) is decisive to the recommendation of the service. Rebecca says:

I think that what they offer is different, you know? That's what keep people there. It's like their slogan says: "Practice your well-being, in every single way." From the entrance until the end of the service. They have a lot of places for people know each other, volleyball, gym, and they also promote a lot of events. Today, I have many friends that I met there. One thing that binds me to the gym is their employees.

The servicescape (Bitner, 1992), the diversity of activities, employees, and other 
customers as friends are some of the competitive advantages elaborated by Rebecca. An interesting particularity of recommendations is that the extrinsic value of the service excellence helps to rationalize its advantages to express to third parties. Hong and Chang (2015) found that customers tend to be more rational and have more reason-based decisions when are making decisions for others. Comparatively, with values derived from an intrinsic dimension, it would be easier to customers to describe potential benefits related to extrinsic benefits. The next sub-dimension of analysis refers to Performance and comprehends the extent to which the service influence customer's performance and self-efficacy. Rebecca's recommendation also alludes to performance, when she explains that:

[Recommending her gym to her friend] is good because we can support each other. You know, when one is not in the vibe to workout... then, the other: "Hey, what time are we going today?". Did you understand? "Let's go together, let's go now!" This kind of support happens every week, almost daily.

The idea of having a company to work out with her and assisting her on keeping her rhythm of exercises also encouraged Rebecca to provide a positive word-of-mouth (WoM). Due to typical features of services (i.e., inseparability and heterogeneity), this value frequently emerged in incidents regarding citizenship behavior of feedback. From an active (and apprehensive) standpoint, Tina revealed:

I gave a feedback to my personal trainer. I was feeling him moody for a long time. Some mood swings, you know? He was sort of angry with me. And that was affecting my work out, my physical activities. Then I called him to have some coffee, outside the gym, to give him a feedback.

In consonance with Vallerand (1997), there are punctual distinctions between extrinsic and intrinsic motivations. While intrinsic motivations comprise feelings of joy, relaxation, and happiness, extrinsic motivations are customarily associated with a little tension and pressure. Since customers' extrinsic goals may depend on their performance, it's common to have a latent feeling of anxiety as experienced by Tina. Furthermore, we suggest the function of Understanding deriving from Clary et al. (1998) and Clary and Snyder (1999) as a subcategory to compose our framework. The function is associated with new learning activities and the possibility of practicing knowledge, competencies, and abilities that are often unused (Clary et al., 1998). Kate described that she participated on a conference and her ultimate motivation to give feedback was getting better ideas in the long term:

It's an event that has a lot to improve [laughs]. There are many things to get better and it's an event that interests me. I can have some benefits from it, you know? And since the event is annual, it's good for me... the greater the level of the event, the more people with a greater level will participate. You can get some benefits in the long run. The better the event, the richer is the exchange of ideas that I can get from it too. 
Performing a citizenship behavior was the best way that Kate found to improve her learning experience at the event. Along the same lines, Gabriel told us about his first encounter with the self-checkout at a large supermarket chain. In the line, in front of him, there was a lady that seemed to be struggling with the barcodes scanning, and he volunteered to help her. When asked if he got any benefit from helping another customer, Gabriel was emphatic about exercising new abilities: "Of course, I learned a bit about it [self-checkout], because I saw the person there. I saw the problem and I didn't repeat it".

Despite personal interests and social environment motivations potential conflicts, they can coexist and create value for all the involved actors (e.g., Bénabou \& Tirole, 2003). In this sense, we advance to the other-oriented view of extrinsic values, coined Social or Esteem to contemplate the social difference from self-oriented dimension. The network view generated by ATLAS.ti regarding Efficacy or quality is available in Figure 2 for better assimilation of the category and its sub-categories.

\subsubsection{Social or Esteem}

Deriving from extrinsic and other-oriented dimensions, the category Social or Esteem comprehends status acquisition, in which CCB activities would be instrumental to build that identity (extrinsic), and status validation that evaluate the social impact of a citizenship behavior (other oriented) (Holbrook, 1999). We divided our category into two subcategories: Networking and Reputation. The perceived value of Networking englobes the establishment of new contacts and strengthening of social bonds. Corinne reported the incident that she displayed tolerance for an employee's lousy performance. The perceived (physical and affective) proximity with her hair salon and its employees motivated her to be sympathetic to the event:

I could have been taken care of for at least thirty minutes before, you know? But I was not annoyed by it either. I think that happened because I already had a relationship with people from the hair salon, the neighborhood's hair salon. 


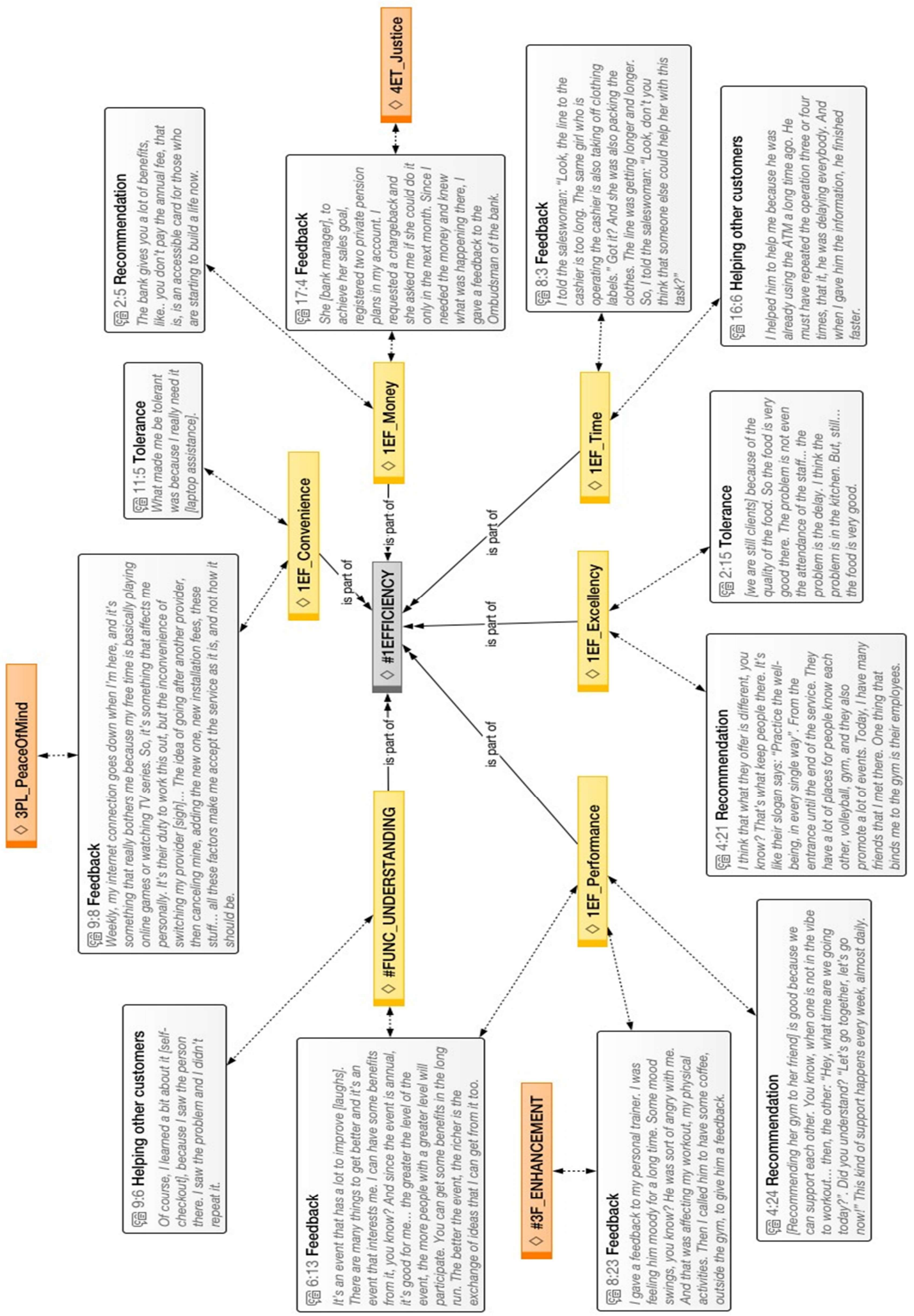

Source: Output from software ATLAS.ti.

Along the same lines, Gabriel told us about a recommendation to his father regarding a new phone. After the successful endorsement, he could see relational benefits from it. Gabriel reported: 
I got the love of my father [laughs], since he adopted the phone. . I think he liked it, you know? I believe that all these little things help to build relationships. If you're satisfied with a product and show that to another person who is equally satisfied, there is a benefit there... in the relationship.

The value of Enhancement, an intrinsic and self-oriented motive associated with our third category, can also be identified due to the feeling of esteem posteriorly reported by him. Customers may provide social capital to the organization (Bourdieu, 1986) due benefits stemmed from their social networks and connections (Portes, 1998; Paxton, 1999). In Rebecca's case, she also considerate benefits to herself when helped a woman who was struggling to communicate with the firm. Rebecca said: "She thanked me and, also, you know... I got her contact. She is the head of marketing of a cruise magazine. She travels all around the world!" The perspective of expanding her network and knowing someone that can bring tangible benefits in the future motivates her to perform a citizenship behavior.

The perceived value of Reputation is fundamentally connected to impression management (or self-presentation) as an effort from individuals to regulate the impressions that others elaborate about them (Leary \& Kowalski, 1990). Individuals are continually attempting to know and comply with social norms and ideal behaviors. This work occurs due to the need to obtain social acceptance and social rewards while avoiding sanctions and punishments such as social disapproval and exclusion (Bellezza, Gino, \& Keinan, 2013; Cialdini \& Goldstein, 2004; Kruglanski \& Webster, 1991). Performing a citizenship behavior allows customers to conform to social expectancies and build trust and status. David told us about a recommendation of an air conditioning installation and maintenance service that he gave to a friend. When elaborating about benefits from it, he said:

The immediate benefit that I can tell is "to be in good eyes" of the company. From the moment you recommend someone, the company will see you in a different way... In the following services, the communication, the relationship becomes more open. The trust changed, in this case.

Another case of recommendation, now exposed by Lauren, also targeted the relationship with the company. Considering herself the "poster girl," Lauren explained that her recommendations helped her to build a reputation with the company and eventually led to tangible benefits:

I always joke saying that I was the poster girl of the company that offers the Intense pulsed light (IPL) for hair removal. At the time, that was news in the city and I was the first of my friends that finished the treatment. I had such a great result that I spread out to everyone! Encouraging them... and a lot of friends did the treatment. By the way, I got many free sessions because of it. Because I recommended to all those people. 
When I like a service, I really recommend it.

Additionally, Loren manifested the status of being the first of her friends to complete the treatment that was a novelty in town. Besides social rewards relative to her pioneering position in her group of friends, we can relate her excitement about the situation to the intrinsic and self-oriented function of Enhancement (Clary et al., 1998). This function underscores positive ego-related motives and will be explored in the next section. Another display of citizenship behavior, tolerance, reflects the compliance with acceptable practices to maintain a reputation, as Charlotte explained:

If I had been intolerant, I would have ripped [the contract with the phone carrier] at that first contact [laughs]. . .In this specific case, I was tolerant because I was at work. I was working and couldn't spend my time on this issue. There were some people around me listening to my phone conversation, so I had to be more tolerant to not create an unpleasant situation in the room, right?

The incident experienced by Charlotte demonstrates an intense public self-awareness in which individuals watch aspects of themselves that third parties can notice to gauge their impressions, such as a behavior or physical appearance (Buss, 1980; Leary \& Kowalski, 1990).

Charlotte's display of tolerance is also connected to self-monitoring, which "refers to the extent to which expressive behavior is guided by situational cues to social appropriateness," and situation congruity due to her working context (Aaker, 1999, p. 47). To schematize our finds in this category, we provide Figure 3 with sub-categories and respective exemplary quotes. Next, we discuss values related to intrinsic motives. 
Figure 3 - Network view of dimension Social or Esteem

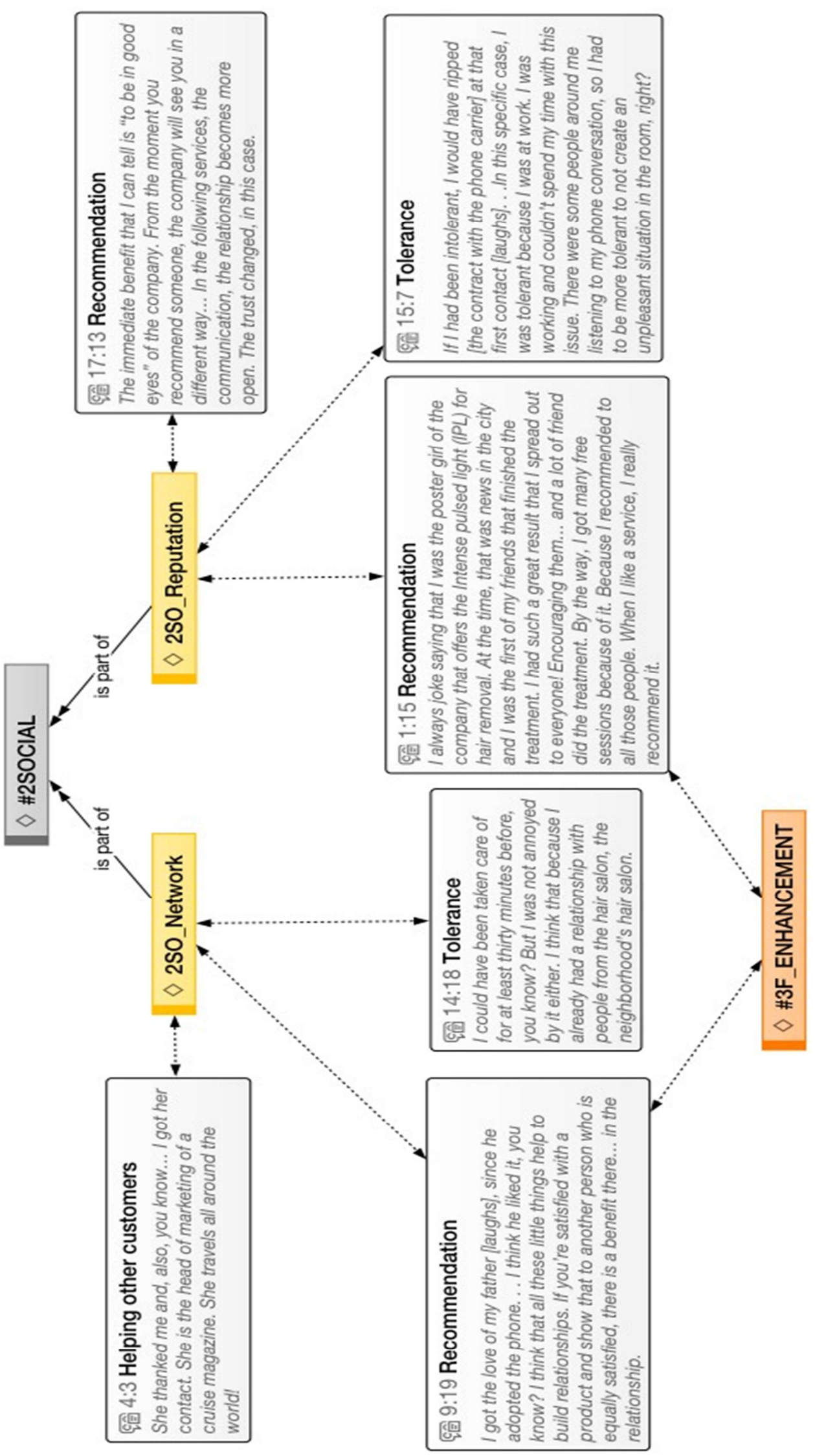

Source: Output from software ATLAS.ti. 


\subsubsection{Play or Peace}

Individuals must choose alternatives to build on their rewards and sanctions and operate complex social situations combining others' and self-interest (Tomasello \& Vaish, 2013, Izuma, Saito, \& Sadato, 2010). Motivations to engage in social behaviors and foster cooperation may be intrinsic (e.g., gratitude, norm following, sense of justice) and extrinsic (e.g., gain trust and reputation) reasons. Our third category is anchored on intrinsic and selforiented values.

Intrinsic values are associated with appreciation for its own sake as ends in themselves, with a detachment to functional concerns (Holbrook, 1999). Our first subcategory, Comforting, encompasses feelings of gratification and satisfaction. Tory had to be patient with a trainee at the store and told us that: "I felt relieved. And it felt good to be patient with him. I think when we do good to someone else, we feel good. It feels like it's a new water that passes through us, you know?" Her report includes other values referring 1) to the Sacredness aspect of the "new water" and renovation by being tolerant; 2) to a Protective dimension that released her from an anticipated guilt (see Massi, 2005) and negative aspects of ego.

Protective and Enhancement compose two different values and subcategories. They are separated since Protective function relates to reducing negative feelings concerning the self and Enhancement connects to the idea of psychological development (Clary \& Snyder, 1999). With distinct proposes, in some cases, they are linked to comprehend different needs of the ego. Protective value can be illustrated by Loren's story can illustrate Protective value:

Loren: Last time, there was a lady at the ATM. She wanted to make some payments and did not know how to do it, how to proceed step-by-step. And I was saying, "now click here, do this, wait..." until it worked. But that's even dangerous, right? Because it's a financial matter. But I'm glad it was me who was there to help.

Interviewer: Why do you think you had the initiative to help this lady?

Loren: Oh, because she was an elderly person, a person who did not know, a person who was having difficulties and ... whenever someone asks me for help, I am willing to help.

Loren may have helped other customer due to the feeling that the lady was less fortunate than her regarding that aspect: she was from another generation who didn't understand the machine nor had familiarity with new technologies, and that was apparently having problems. Enhancement values, in another stream, are based on the positive feeling of self-confidence and self-esteem and serve another mechanism that emphasizes help (Clary et al., 1998). Another example of Enhancement is provided by Rory. She explained that she was feeling the employees of her gym less engaged with customers and gave feedback to the firm 
to improve the quality:

So, I was kind of hopeless but trying to make a difference. But when I saw the result in practice I was very happy to have given in to something, if it was the result of my suggestion.

Rory said that, a couple of weeks later, she could feel personal trainers more engaged and participative. Trying to make a difference, even that hopeless, she had a feeling of esteem and empowerment. The next value corresponds to a Peace of mind, a state of stress avoidance and emotional balance. This specific value was almost omnipresent in all displays of tolerance due to its inner characterization (intrinsic value). As Kate and Rebecca respectively unveiled:

A case that I had to breathe deeply and be tolerant was due to my internet provider. When I wanted to cancel the service, the connection would have dropped 20 times. Then I had to call, start everything from scratch, and thus, take a deep breath and pretend that nothing has happened there. And go! You can either keep it up to cancel the service or you're going to be angry, and you're going to feel upset and have to call again to cancel anyway. So, talking and fighting wouldn't help my peace of mind. I waited.

Because I noticed it was going to take a long time, I'd have a headache to solve something simple, you know? It would be more practical for me to settle on my own and have a financial loss than to have a headache of waiting until they can help me with the value of repair.

Both cases exemplified the preference for keeping their peace, being tolerant with the service provider even with losses of time and money. The last value of Happiness incites feelings of enjoyment and delight that represent the intrinsic motivation of performing an activity for the process of helping per se (Berlyne, 1966; White 1959). When Rose recommended her doctor, she told us that she was ecstatic to help her friend and loved the good feeling afterward: "I think it only brought benefits because my friend got there and she had as positive results as mine. So, I was more than happy to be able to help her." Also, Kate highlighted the joy for helping a little girl and her parents to understand how to use a bike in the sports store:

I think that I could have helped even more, you know? If I have had talked more with her mom. I helped the little girl twice, explaining her how to synchronize her legs and holding her to practice a bit. Then I left the girl with her mother, but you feel very happy when you know that you can help someone. 
Figure 4 - Network view of dimension Play or Peace

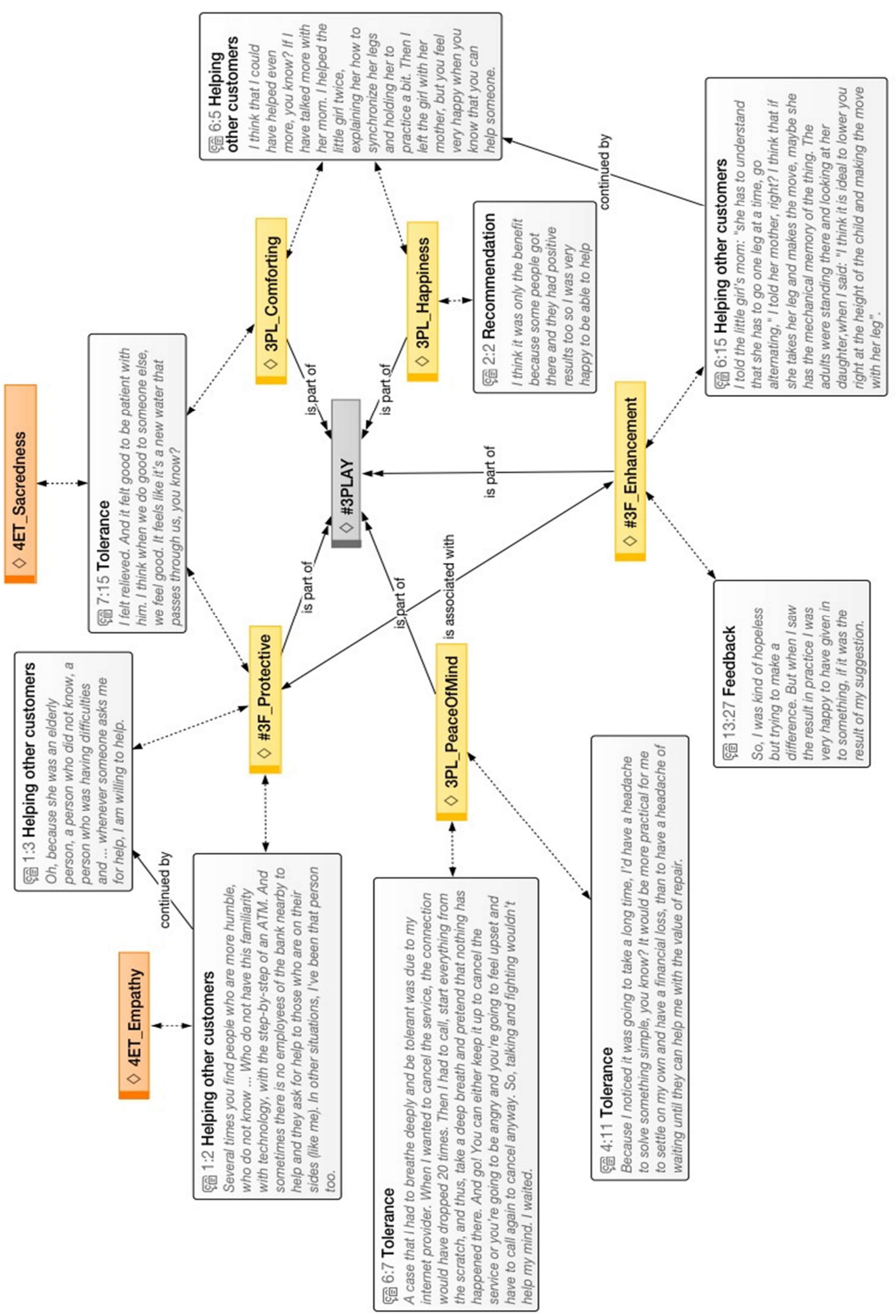

Source: Output from software ATLAS.ti. 
Kate, in this case, also presented an intrinsic self-oriented value of Enhancement, since she could help when no one else could (nor the little girl's parents or the unavailable salespeople). In Figure 4, we show the network view of the Play or Peace dimension with supplementary quotations to illustrate the discussed subcategories and its dynamics. Next, we still consider intrinsic values, but now focusing on the other-oriented dimension, composing the category of Ethics or Spirituality.

\subsubsection{Ethics or Spirituality}

Our last category comprises intrinsic and other-oriented values to perform CCB. According to Holbrook (1994), ethics involve doing something for the sake of others, with consideration of how it will influence or impact them. Altruism, the first subcategory, occurs without the pretension of being rewarded from others (Bar-Tal, 1976; Krebs, 1970). In fact, an altruistic behavior consists in voluntarily giving a benefit to another actor, even if the act can be detrimental to the giver (Trivers, 1971). It can also be defined as a motivational state that seeks another person's well-being (Batson \& Shaw, 1991). When evaluating the perceived value of Altruism, it differentiates from Benevolence due to the idea of "doing good at all costs," even if prejudicial to the one performing the activity. John had recollections of the day that he was in the line to withdraw some money and saw an old man struggling with the machine. Although initially hesitant, he decided to help the other customer. He said:

When you approach a strange person at an ATM ... I think you feel a little ... "What are people thinking?" Maybe they are thinking that I'm trying to take advantage from that vulnerable person who doesn't know how to operate the device. Because this happens a lot, right? There are many cases of people being cheated at ATMs, who are even stolen. But I'd rather do a good deed and help someone in need than care about what the others in line are thinking.

Even aware of potential social punishments from others in line (e.g., damage to his reputation or social exclusion), he decided to engage in the citizenship behavior. This incident reveals sources of conflict between intrinsic and extrinsic values towards others (i.e., Social versus Ethics) (Ryan \& Delci, 2000). Loren experienced a distinct situation with a cabinet maker regarding her altruistic motives. She told us that she had to be tolerant to comply with it:

I felt harmed because I lost the space of my old furniture, right? He did a smaller one, to be honest. So, my loss was that. And then I had to pay a full price because he didn't give me any discount. I ended up letting go. 
Further, Loren clarified that the cabinet maker was "a really humble man" that "didn't have money" and "was looking for jobs to support his family". Her Protective values (self and ego-oriented), to avoid guilty, played a substantial role in her choice of being patient. Along similar lines, being cooperative is considered a conspicuous act of Benevolence (Sylwester \& Roberts, 2013; Simpson \& Willer, 2008). Corinne and Carl helped other customers to "emphasize acceptance of others as equals and concern for their welfare" (Ros, Schwartz, \& Surkiss, 1999, p. 53). Corinne detailed the incident:

She saw that I picked up a shirt and asked me where she could find it because it was a department store. Then, she was holding some clothes and started to ask me what I think about it. I was her fashion consultant [laughs] telling if she would look too old or clearing up any doubt that appeared about her clothes.

Carl said,

I saw that no one was able to help him, on the spot. The salesman was standing there, and the guy was kind of restless because the salesman could not communicate in English. Then, I thought "oh, I have to do something here." I went there, and I helped. There was no one else reachable at that moment.

Interestingly, Carl's situation is also related to the fact that "he had to do something here" and there was no one else to help. He handled the situation and demonstrated being proud of himself. Protective and Enhancement functions are intimately connected to his motivations for performing a CCB. Protective to attenuate possibilities of remorse or regret for not helping and Enhancement due to the positive boost of self-confidence and delight.

Empathy is our third subcategory. De Waal (2008, p. 281) affirms that "empathy is the capacity of (1) be affected by and share the emotional state of another, (2) assess the reasons for the other's state, and (3) identify with the other, adopting his or her own perspective". Tina disclosed her a critical incident permeated by the identification with another customer in a similar situation than hers. She told us that:

Recently, I was at a store with great sales. I'm size 12. And I saw at the cashier... the girl telling the saleswoman: "Oh, I can't find a piece of clothes size 6 that I would like to buy." Then, I went to the other side of the store looking for some belts and saw a pants size 6. So, I took the pants and showed her, sort of working like a saleswoman.

As Tina knows the feeling of not being able to find clothes of her size, she tried to help the other customer with it "working like a saleswoman". Groth (2005) disseminated the idea of customers being partial-employees as an essential tool to develop competitive advantages.

Morality and justice are values considered "for its own sake as its own reward" and entail the idea of duty to others, besides "appear in the form of socially accepted rules of 
conduct or conventions that dictate proper behavior (Holbrook, 1994, p. 37). Engaging in citizenship behaviors can meet necessities regarding moral obligations and justice. Anne gave feedback to the pizza delivery due to its delay and said that "somehow, we fought for our rights. So, we made contact to complain. Someone had to be responsible for this situation, for this complaint." The underlying idea of "the right thing to do" also permeated Tory's report:

I gave the feedback and did the evaluation. I really like to make an evaluation. And I enjoy giving feedback to people's bosses. When it is a service that stands out, I like to leave where I am and even look for the manager of the store to tell him. Because I think this can... If the person is needing just a push to have a transfer, or to have a progression, a promotion, I will not miss the opportunity to offer the praise that the person needs for it.

The structure of reciprocity is also underscored when linked to Moral and virtue. Reciprocity can inform us about social relationships in the realm of exchange, trust, and solidarity (Molm, 2010). An appropriate illustration is David's incident. He commented that his bank manager tried to dissuade him to give a feedback to her superiors, as he commented: "She asked me not to do it, but that was above a relationship of friendship. I think company and customer must cultivate something bilateral: I respect, and she respects me as well."

When approaching Sacredness in his framework of values, Holbrook (1999) highlights the intrinsic value of faith, magic, believing in a mystical entity, or in the Divine Power. This value is spiritual in nature and involves diverse types of devotion and worship. Tolerance has been commonly associated with an elevated spiritual state due to its resilient feature. Tory reminded the incident when she had to buy school supplies for her children and had to be patient with a slow employee. She commented the episode as a lesson sent from God to practice her tolerance. Tory said:

Patience is always something good. When you say: "God, give me patience!". God doesn't provide patience to you, He gives situations to practice and raise your patience, having patience. Right? So, I believe we always improve ourselves when we have patience, tolerance. And try to understand that situations will never be perfect.

Belk, Wallendorf, and Sherry (1989) clarify that the sacred is related to "a need to transcend existence as a mere biological being coping with the everyday world" (p. 2). That is, it can't be apprehended cognitively. 
Figure 5 - Network view of dimension Ethics or Spirituality

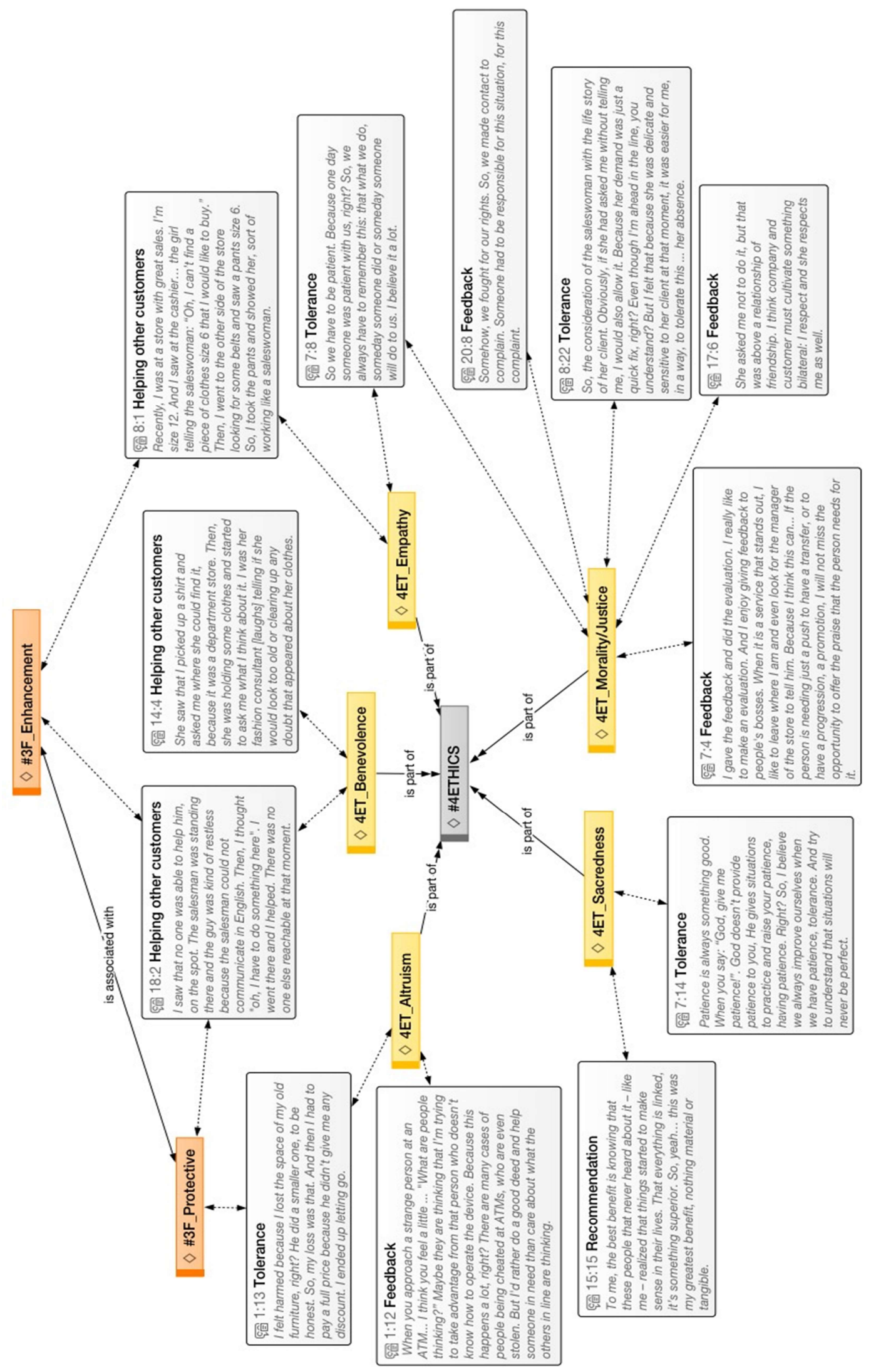

Source: Output from software ATLAS.ti. 
The sacred commands love, fear, devotion, and is instead an emotional experience than rational thinking. Charlotte recommended a homeopathic doctor to her dentist and offered her some comprehension about the holist essence of the service. She reported:

To me, the best benefit is knowing that these people that never heard about it-like me - realized that things started to make sense in their lives. That everything is linked, it's something superior. So, yeah... this was my greatest benefit, nothing material or tangible.

In her case, helping someone may be a way to bring awareness of the world complexity and abstractedness, denying "material or tangible" benefits. The active initiative of recommending a service with a connection to spirituality to someone makes the helping process rewarding to Charlotte. Ethics or Spirituality comprises a series of six sub-categories that helps to understand $\mathrm{CCB}$ towards company and customers (see Figure 5). In the next section, we offer final considerations regarding our study.

\subsection{General Discussion}

We investigated how customers perceive value on performing CCB. Building on the previous theorizing from Holbrook (1994, 1999) and Clary et al. (1998), we integrated emerging patterns of motivations to different types of values. We proposed a framework to analyze what encourages customers to perform discretionary behaviors towards the company and other customers. Considering dichotomies of self-oriented versus other-oriented and extrinsic versus intrinsic values, we also discussed the dynamics of values and particularities of specific dimensions of CCB (i.e., helping other customers, feedback, recommendation, and tolerance).

Customers have a wide range of options to perform citizenship behaviors due to its discretionary engagement (Bettencourt, 1997). When analyzing the Efficiency or Quality category, we found that values encompassing Money, Time, and Convenience were critical to understanding $\mathrm{CCB}$ during the service experience. As instrumentals goals to help customers to achieve the "long run to self-interest" (Trivers, 1971; Hamilton, 1964), customers will perform citizenship behaviors to attain extrinsic benefits to themselves. The subcategory Understanding, one of our contributions, also highlighted a salient and underexplored facet of CCB. To practice an unused or underdeveloped competence, knowledge or skill, customers will engage in helping other customers and elaborate feedbacks to the firm (e.g., exercising another language or handing a new technology). Interestingly, the mechanism of help per se may assist customers in the future: for example, a participant that reported that the process of 
giving feedback to the firm changed and supported her to deal with subsequent feedbacks issued by her and directed to her.

P1: Citizenship behaviors based on efficiency or quality motivations will enhance self-oriented value.

Individuals are continually choosing alternatives to build on their rewards and sanctions to operate complex social situations combining others' and self-interest (Tomasello \& Vaish, 2012, Izuma, Saito, \& Sadato, 2009). Based on Social or Esteem category, we noticed the pattern with different types of CCB. Helping other customers and giving recommendations allow customers to publicly demonstrate concerns regarding others while communicating self-identity aspects (Shavitt, 1990). Since helping, giving feedbacks, and making recommendations require some active effort from customers, these behaviors may also assist on perceived values related to reputation building both with the firm and social groups, such as other customers, family, and friends. Based on the essence of extrinsic and other-oriented values, these behaviors are fundamentally connected to impression management. Furthermore, the establishment and development of social bonds (i.e., Networking and Reputation) would help customers to achieve personal and professional benefits.

P2: More active or effortful citizenship behaviors (i.e., helping other customers, giving feedbacks, and making recommendations) will be more related to reputation building and social bonding when compared to more passive CCB (e.g., tolerance).

As expected, when examining values regarding the Play or Peace category, we recognized that perceived value of CCB might not be directed to the company's success or other customer's welfare. Instead, a customer may engage in citizenship behaviors to deal with their peace of mind, enjoyment, and ego-related issues (i.e., Protective and Enhancement).

P3: Customers with high self-orientation will be more willing to perform $\mathrm{CCB}$ regardless of the company's performance.

The "compresence" (Holbrook, 1994, 1999) of these intrinsic/self-oriented perceived values with other dimensions was recurrent in performing CCB. It also gives us essential hints about cognitive dissonance on citizenship behaviors. For example, the case reported by Loren in which, despite the lack of quality of the service, she was tolerant due to the anticipated guilt of being prejudicial to a worker with humble origin.

P4: The feeling of anticipated guilt will increase the willingness to help other customers (CCB-C) and employees (CCB-E) of the firm. 
Discussions comprehending the Ethics and Spirituality category highlighted the perceived value of Morality and Justice on engaging on citizenship behaviors. Being fair to the environment and acting towards social justice are particularly important to customers. Benevolence and Sacredness also revealed pivotal values, since CCB may be a platform to do a concrete action for a greater good.

Services and products evoke different needs and desires from their customers (Hirschman \& Holbrook, 1982). That is, functional products are connected to consumptionrelated issues that seek to solve a problem or conflict, while experiential products are related to sensory pleasure. The characterization of the service can influence the way customers act towards the firm due to its complementarity to value source (Peloza \& Shang, 2011). In this case, extrinsic and intrinsic self-oriented values ("help the firm to help me") have a crucial distinction since the first will be highly salient in a functional service context and the second will be highly conspicuous in an experiential circumstance.

P5: The nature of the service will influence the perception of value to perform CCB. Extrinsic/self-oriented values will increase the salience to perform $C C B$ in functional settings. Intrinsic/other-oriented values will increase the salience to perform CCB in experiential settings.

It should be noted that helping the company, employees, and other customers is not a straightforward process with direct results. Although CCB has been associated with positive antecedents and outcomes (e.g., Groth, 2005, Bove et al., 2009), customers may engage in displays of tolerance to cope with their protective function or feelings of impotence towards the service experience (Clary et al., 1998). These behaviors are beneficial to the firm in the short term but may harm customer-company relationship due to its passive and reactive nature. With a perceived low control regarding extrinsic gains, they tend to look for more intrinsic values on performing CCB.

P6: Faced with low control regarding service settings, customers will focus on intrinsic values on performing $\mathrm{CCB}$.

An emergent issue on our study was the inconsistency between helping employees and helping the company. Sometimes, being able to help employees (e.g., cover for their mistakes in front of other customers) may be detrimental to the firm's performance maintenance in the long run. The gap of interests between these two parties may trigger perceptions of low cohesiveness regarding the company/brand and cause damages to the customer-company identification. Further, conflicts regarding perceived value may arise: being benevolent or being fair? 


\section{P7: Conflicts with other-oriented values of $\mathrm{CCB}$ will trigger perceptions of low cohesiveness and customer-company identification.}

The salience of social norms even in a private context, as used in Goldstein, Cialdini, and Griskevicious (2008) study, may help firms to control citizenship behaviors related to extrinsic and self-oriented benefits. Furthermore, marketers can influence perceived low control of customers by ensuring them with physical evidence and guarantees to try to mitigate problems on their relationship with the brand. Since the variance of service quality may be an issue, marketers could work with cues connected to ego-related perceived values to improve tolerance, feedback, and help during the service encounter (e.g., communications signaling empowerment). Lastly, as a suggestion, managers should also develop communications channels at different levels in the organization and institutionalize more points of contact with customers to discourage undesirable and incoherent behaviors from other customers and employees.

Future studies may explore the value of CCB by helped customers and employees of the firm. CCB literature is still concentrated on customers who help rather than the ones helped. Other types of citizenship behaviors, such as advocacy, cooperation, and facilitation may comprehend different perceived values and sources of motivation than those explored in this study. Furthermore, studies could examine how negative behaviors of the firm, such as reduced performance of employees and negligence during the service delivery, may trigger citizenship behaviors. For example, customers may assume the role of a salesperson observing employee's lack of abilities to communicate with other customers. Besides, referring to the "dark side of CCB," studies could try to understand how intangibility and heterogeneity may negatively affect the service's outcomes (e.g., imprecise information) through CCB. Another stream of research is to investigate factors or mechanisms that would increase the propensity of customers to engage in voluntary behaviors (product category, group entitativity, etc.) and minimize potential barriers for helping (e.g., low self-efficacy, self-awareness or self-esteem). 


\section{4 “IT'S NOT YOU, IT'S ME": HOW CORPORATE SOCIAL RESPONSIBILITY DECREASES CUSTOMER CITIZENSHIP BEHAVIOR}

\subsection{Introduction}

Whether working out at the gym, having lunch at the restaurant, traveling on vacation, or buying new clothes, when customers look around, they are surrounded by people sharing the same venue with similar needs and purposes. Eventually, these fellow customers may need opinions about a new gadget, instructions on how to adjust gym equipment or even a lesson on how to self-check-in at the airline kiosk. The possibilities of consumers helping each other vary across services and emphasize its dynamic and interdependent nature. With investments in technology-based, technology supported services, and customers' empowerment (e.g., Bitner, Brown, \& Meuter, 2000; Cova \& Dalli, 2009), companies have interest in fostering customer voluntary behaviors that traditionally have been operated by employees (Groth, 2005). Thus, these discretionary extra-role actions performed by consumers during service delivery, coined Customer Citizenship Behavior (CCB), are critical on promoting service quality and customer satisfaction besides creating a favorable climate service (Balaji, 2014; Bettencourt, 1997; Bove et al., 2009; Johnson \& Rapp, 2010; Kim \& Choi, 2016).

Companies are increasingly fostering interactive encounters among their actual and potential customers. Initiatives such as brand communities (Algesheimer, Dholakia, \& Herrmann, 2005; Muniz \& O’Guinn, 2001), online forums (e.g., Moe \& Trusov, 2011), social campaigns (e.g., Peattie \& Peattie, 2003), and events and fairs help to mobilize customer towards moral responsibility, shared identity, and social consciousness. In the same stream, Corporate Social Responsibility (CSR) programs are rising due to public pressure and customers' greater willingness to purchase products from these firms (Pérez \& Del Bosque, 2015; Pirsch \& Gupta, 2007; Sen \& Bhattacharya, 2001). They are grounded on salient social identity and self-definitional needs (e.g., Marin, Ruiz, 2007; Matten \& Moon, 2008). Whereas the increasing interest in CCB in recent years is notable (e.g., Anaza, 2014; Choi \& Lotz, 2016; Thompson, Kim, \& Smith, 2015), there is a scarcity of authors that approached the influence of CSR on citizenship behaviors. On one hand, the number of companies investing on CSR activities such as cause-related marketing, corporate philanthropy, and minority support programs have exponentially increased in the last decades (Bhattacharya \& Sen, 2004; Lii \& Lee, 2012; Luo \& Bhattacharya, 2006). On the other hand, CCB integrates avenues for social capital, customer co-creation of value, firm recognition and reputation (Bettencourt, 
1997; Nguyen, Groth, Walsh, \& Hennig-Thurau, 2014). Lii and Lee (2012) found that philanthropy was the only CSR initiative to influence in-role and extra-role intentions through customer-company identification and brand attitude as mediators. Despite initial efforts, there is still a need for novel and counterintuitive empirical findings on these research domains.

Drawing on social identity theory, we propose CSR as part of a desirable self-concept in which "we" is a priority instead of "I". We posit that CSR attends collective goals that reinforce shared values and "perceived similarities between the self and other in-group members" (Stets \& Burke, 2000, p. 225). Since social identity assumes that people determine their self-concept by connecting with social groups and organizations (Tajfel \& Turner, 1979), they tend to assume corresponding roles and responsibilities. The theory offers a bridge between the self and social entities (Belk, 1988; Lam, Ahearne, Hu, \& Schillewaert, 2010).

We also adopt the self-completion lens to argue that social identification is a necessity that can be satiated by complying with CSR initiatives. Self-defining goals (i.e., belonging to a group or consolidating social self) have multiple indicators or symbols that are exchangeable for one another (Wicklund \& Gollwitzer, 1981). People seek to satisfy self-defining-goals and being a good citizen is a goal commonly shared, such as doing good for people close to you, people in need, or yet fellow customers. Since helping is only one of self-defining dimensions, helping some individuals may reduce the propensity to help other individuals. The abstractedness of innumerous routes to attend self-defining goals may lead people to disengage of their goal or bring impatience on seeking "progress" that cannot be measured or premeditated.

Interestingly, consumers can fulfill their goals in various ways. As such, they are likely to embrace more accessible and immediate ways of self-symbolizing to anticipate gratification (Gollwitzer \& Sheeran, 2006). As a result, because consumers are likely to disengage after perceiving progress toward a self-defining goal (Wicklund \& Gollwitzer, 2013), consumers are less likely to engage in other forms of satisfying self-defining goals of social identity after complying with CSR initiatives. For example, an initial token display of support for a cause at the fast-food cashier (e.g, donating US\$1 to the Red Cross) may decrease the chance of a subsequent display of support to another customer (e.g., teaching someone how to use the soda fountain machine). As a result, we propose, counterintuitively, that by endorsing CSR actions and achieving self-definition goals, customers may inhibit posterior displays of CCB (i.e., helping fellow customers) considering that they already obtained satisfaction for helping third parties.

This study offers several contributions. First, we extend the logic of social identity and 
self-completion theories for a more micro level field in which we connect to CSR and CCB. Further, the proposition of CSR as an inhibitory variable instead of a trigger to citizenship or desirable behaviors is counterintuitive and offers new paths of research (e.g., Marin, Ruiz, \& Rubio, 2009; Ramasamy, Yeung, \& Au, 2010). Second, we inaugurate the boundary condition of customer entitativity (Lickel et al., 2000; Rydell \& McConnell, 2005) as a mechanism underlying these effects. Proximity, similarity, and interdependence characterize entitative groups (Effron \& Knowles, 2015). Third, we contribute to self-completion theory by bringing to light entitativity as a relevant condition that attenuates issues (i.e., impatience and overextension) related to self-defining goals. These conflicts affect the development of behavioral competencies, and may damage communication and interpersonal relations (Wicklund \& Gollwitzer, 2013). Lastly, we focus on the often-overlooked CCB dimension of helping other customers to better understand how CSR initiatives influence discretionary demonstrations of citizenship among customers. In this case, feedback, recommendation, facilitation, cooperation, tolerance, and advocacy are dimensions that don't benefit other customers directly (e.g., Balaji, 2014; Curth, Uhrich, \& Benkenstein, 2014; Yi Nataraajan, \& Gong, 2011).

Two following experiments demonstrated the effects of CSR on CCB. In Experiment 1, we tested our core proposition by exposing respondents to CSR versus neutral conditions of an existing company. The ones in the neutral condition were more predisposed to assist other customers afterward. In Experiment 2, we replicate our main finding with three different companies and different stimuli from Experiment 1, besides adding a boundary mechanism that moderates the relationship between the adherence to CSR initiatives and helping fellow customers.

\subsection{Experiment 1}

Our primary goal in Experiment 1 is to investigate the core premise that due to selfcompletion, people tend to feel satiated on complying with social expectations reflected on CSR. Thus, we posit that customers exposed to a neutral condition will be more willing to perform citizenship behaviors towards other customers since they didn't have the previous opportunity to attend to their self-definition goals concerning social identity. Respondents in the CSR condition will be less willing to help other customers in a second circumstance. 


\subsubsection{Participants}

Two hundred and fifty American members of a community-based subject pool participated in our study in exchange for monetary compensation $(62,8 \%$ female, Mage $=$ 43.95 $\mathrm{SD}=14.193$ ). Each respondent was randomly assigned to one of the two established conditions of the study.

\subsubsection{Manipulations}

We employed a one factor (firm products: CSR vs. neutral) between-subjects design. Participants were exposed to a cover story in which we would ask their opinion to estimate sales of Microsoft's new products for 2018. To manipulate our independent variable (IV), half of the respondents received a condition with two software bundles that Microsoft is considering to launch: both had the same description, but one offered an additional application called Math Works while the other was Microsoft Groups (fictional products). They were asked to choose one of the packages. The other half of participants, assigned to the CSR condition, also received the same bundle, but this time with the possibility to choose between the adherence of " 1 subscription $=1$ tablet" campaign that would give one table for each subscription to Boys \& Girls Clubs of America (BCGA) or Technology Education and Literacy in Schools (TEALS). Similarly, they had to choose a package between the two causerelated marketing (CRM) initiatives (Appendix A).

In this experiment, CSR condition was based on a CRM choice since it would require participants to make a choice and, thus, demonstrate progress towards self-defining goals. We hypothesized that participants directed to CSR condition would be less willing to help other customers in a short-term opportunity.

\subsubsection{Procedures}

Firstly, participants were assigned to one of the reported conditions (CSR or neutral). They were asked "which package would you choose?". After choosing the bundle, we thanked them for participating in our poll and introduced the Microsoft Users Hub, a new hub for users to post questions and answers about how to optimize the use of Microsoft products and services. Then, we asked them to select all e-mail lists that they would like to sign up for: "I would like to be notified when users post questions on my area of expertise, so I can help them to solve their problems"; "I would like to be notified when other users respond to questions within my area of expertise, so I can help by rating the quality of their responses"; and "none 
of the above". They were informed that they would be actually signed up for the lists selected, thus making their choices consequential. After answering our dependent variable, participants answered to manipulation and attention check questions. Next, participants indicated their demographics, were informed that they would not be signed up to any list and that we had not collected any identifying information, and were dismissed. We used a behavioral dependent variable (i.e., sign up to e-mail lists) to expand our finding beyond intentions to help (Groth, 2005; Parker \& Ward, 2000).

\subsubsection{Results and discussion}

Due to the count nature of the data, we analyzed the data using a Generalized Linear Model (GLM) with Poisson distribution and Log link (Dobson \& Barnett, 2008; McCullagh $\&$ Nelder, 1989). To test our hypothesis, we included a dummy variable for CSR ( $1=$ CSR, 0 $=$ control) as the independent variable, and the number of lists the individual signed up for $(0$, 1 , or 2) as the dependent variable. Conforming our prediction, we found a main effect of CSR $\left(\beta=-.112, \chi^{2}(1)=3.834, p<.05\right)$ such as respondents in the CSR condition presented a lower $\mathrm{CCB}$ engagement than those in the neutral condition.

CSR seems to be associated with satisfied self-defining goals that decrease the necessity to perform a helpful behavior in the sequence. As assumed with the realism of the task (respondents were asked to subscribe to e-mail lists to help other customers) and on previous research on helping behaviors, the level of help was low but, when faced with a previous CSR choice, the level was even lower (0.8\% and 3.2\%) as shown in Table 16.

Table 16 - Cross tabulation of means (percentage)

\begin{tabular}{|c|c|c|c|c|c|}
\hline & & $\begin{array}{l}\text { Cross tabulation } \\
0,00\end{array}$ & 1,00 & 2,00 & Total \\
\hline \multirow{2}{*}{ CSR } & 0 & $88 \%$ & $5,6 \%$ & $6,4 \%$ & $100 \%(125)$ \\
\hline & 1 & $96 \%$ & $0,8 \%$ & $3,2 \%$ & $100 \%(125)$ \\
\hline Total & & $92 \%$ & $3,2 \%$ & $4,8 \%$ & $100 \%(250)$ \\
\hline
\end{tabular}

Study 1 established the expected effect of complying with CSR activities on their willingness to tighten bonds with other consumers through CCB. Consistent with literature on community identification, $\mathrm{CCB}$ is likely to emerge when people perceive other customers as partners who share common interests, as opposed to mere acquaintances that happen to consume similar products (Johnson, Massiah, \& Allan, 2013; Johnson \& Selnes, 2004). Research has shown that certain groups are composed by members that are perceived to form a cohesive entity, with similar characteristics and shared goals, that is, are perceived to have 
high entitativity (e.g., Hamilton, Sherman, \& Lickel, 1998; Hogg et al., 2007; McConnell, Sherman, \& Hamilton, 1997). Extant literature shows that individuals use group membership to satisfy social identity goals only when the group is perceived to have high entitativity (e.g., Crawford, Sherman, \& Hamilton, 2002; Smith, Faro, \& Burson, 2012). Thus, if satiation of social identity goals indeed underlines the effect of complying with CSR activities on CCB observed in study 1 , then we expect entitativity to moderate this effect such that complying with CSR activities will reduce CCB only when the individual perceive that the consumers of the brand form an entity (i.e., the group of consumers has high entitativity). We test this hypothesis in study 2 .

\subsection{Experiment 2}

This experiment tested the extent to which high entitatitivity could attenuate the adverse effect of CSR on CCB. Specifically, we imply that differently from low entitative groups, that present a wider variance among members, inferences regarding high entitative groups are more generalizable and transmissible to other members. Predictable inferences about high entitative groups may facilitate information processing and increase willingness to help in a second task.

\subsubsection{Participants}

One hundred and nineteen American participants of a community-based subject pool participated in our study in exchange for monetary compensation $(62.2 \%$ female, Mage= $44.82, \mathrm{SD}=13.60)$.

\subsubsection{Study design and materials}

As in study 1, participants were randomly assigned to one of two conditions: CSR and neutral. We adapted the stimuli used by Habel, Schong, Alavi, and Wieseke (2016) to manipulate both scenarios. Participants were asked to evaluate one company from a set of three, totalizing 40 respondents per firm (i.e., Apple, Ikea, and Starbucks). The three firms 
represented a small sample of the list of cross-industry global brands provided by Interbrand1. In a first moment, participants in the neutral condition (approximately 20 for each company) read a brief description of the company (around 100 words). To the experimental group, besides the short text, we presented an additional fragment with a description of a prominent CSR initiative from the company (approximately 180 words). The additional paragraph detailed real actions promoted by firms. Following the steps of Habel et al. (2016), we were careful to structure the fragments as comparable as possible. Participants in the neutral condition didn't have access to information regarding firm CSR activities (Appendix B).

\subsubsection{Procedures}

After asking for reading information about companies in the neutral and CSR conditions, we told participants that we were planning to launch a customer community. Thus, participants were asked how likely they were to "teach someone how to use a product correctly" and "explain to other customer how to use a product correctly". They rated the sentences based on a seven-point Likert scale $(1=$ not at all likely and $7=$ extremely likely $)$. Our dependent variable was adapted from the "helping other customers" dimension of Groth (2005).

With the purpose to measure the role of entitativity in these effects, the indexes were borrowed from Lickel et al. (2000). They rated the statements "I feel that Apple/Ikea/Starbucks customers are a unit", "I feel Apple/Ikea/Starbucks are as one", and "I feel that Apple/Ikea/Starbucks customers qualify as a group" using a seven-point Likert scale $(1=$ Strongly disagree and $7=$ Strongly agree $)$. Upon completing the entitativity scale, participants were asked to answer the perceived company CSR engagement scale proposed by Habel et al. (2016) as manipulation check. Attention check was also verified before following to demographic questions.

\subsubsection{Results and discussion}

To verify our hypothesis, we conducted a moderation analysis (model 1; Hayes, 2013). We regressed CCB on entitativity $(1=\mathrm{CSR} ;-1=$ control $)$ and their interaction. As predicted,

\footnotetext{
${ }^{1} \mathrm{http}: / /$ interbrand.com/best-brands/best-global-brands/2017/ranking/
} 
we found a significant interaction $(\beta=-.356, \mathrm{t}=-2.273, \mathrm{p}<.05)$. We also found a marginally significant effect on entitativity $(\beta=.2721, \mathrm{t}=1.73, \mathrm{p}=0.08)$. CSR had no significant effect $(p>0.10)$. More importantly, we performed a simple slope analysis to probe the interaction and found a significant effect of CSR at high entitativity (operationalized as 1 SD above the mean; $\beta=-.45, \mathrm{t}=-1.95, \mathrm{p}=0.05)$ and a non-significant effect of CSR at low entitativity (operationalized as $1 \mathrm{SD}$ below the mean; $\beta=.31, \mathrm{t}=1.29, \mathrm{p}>.10$ ).

Results of Experiment 2 reinforced our main proposition tested on the previous study that CSR helps to decrease customer engagement on helping other customers. When participants evaluated customers' entitativity regarding the brands, we observed that those who rated highly in entitativity had more propensity to display citizenship behavior (i.e., helping and teaching other customers). These predictions are probably due to associations of entitativity with shared values and social identity. Furthermore, the perception of the group of consumers as a unit helps to reduce the effort of processing information and improves the identification of outcomes and efficacy on performing these behaviors towards strangers (Wicklund \& Gollwitzer, 2013).

It is also important to mention that we failed to replicate the main effect of CSR on $\mathrm{CCB}$, finding it only when the entitativity of the group was high. We speculate that this might have been because of the less involving task used in Study 2, since people were just reading information about the company rather than making consequential choices about CSR related products.

\subsection{General Discussion}

Our main objective in this article is to analyze how a company CSR activities can influence helping behaviors among their customers. Based on two studies, we postulate and demonstrate that when participants were faced with a previous opportunity to satiate selfdefining goals through CSR, they had a reduced propensity to help other customers (i.e., citizenship behaviors). Further, we also suggest that these findings are part of a phenomenon called overextension and impatience that attenuate the willingness to help in a second

opportunity (Wicklund \& Gollwitzer, 2013). Ego depletion, that refers to the idea of completing a task which produces a temporary reduction of self-control to perform a second one, provides a subsidiary explanation to the observed results (Wicklund \& Gollwitzer, 1981). 
We focus on the understudied role of entitativity in the second study to understand underlying factors that may affect this process. Entitativity is closely linked to attributions and impression formation (e.g., Yzerbyt et al., 1998). Besides, differences regarding groups entitativity have relevant consequences on how perceptions about these groups are processed (Rydell \& McConnell, 2005). Specifically, we offer support for our proposition with moderation evidence in this article, as well as showing that those participants who perceived a higher entitativity among customers of the companies were more willing to help others in a following situation. Characteristics of entitativitiy among helped members, such as similarity, proximity, homogeneity, and common goals, can impact and attenuate the overextension perception in addition to elicit social identity cues (e.g., in-group identification). In this sense, comprising a coherent unity may improve the propensity of customers to more frequently assist the company through different situations and programs (i.e., towards CSR activities and other customers' needs).

We extend previous research on CSR addressing the adverse effects on CCB. We show a negative facet of CSR that is still underexplored in the literature (e.g., Luchs, Naylor, Irwin, \& Raghunathan, 2010). Also, we provide behavioral support for our claim with our dependent variable on Study 1. The number of studies on CCB literature has grown in recent years, but no research has analyzed this effect and underlying factors that can attenuate undesirable behaviors. Precisely, the few efforts that connected CSR to CCB presented a beneficial side of that relationship (e.g., Karaosmanoglu, Altinigne, \& Isiksal, 2006; Lii \& Lee, 2012). We also focus on helping other customers, a specific dimension of $\mathrm{CCB}$, to understand the extent which customers are willing to go to help the firm. Additionally, we contribute to selfcompletion theory by suggesting the promotion of entitativity as a path to attenuate overextension and other issues that can harm self-defining goal attainments and social sensitivity. Wicklund and Gollwitzer (2013) affirm that there is a constant tension associated with self-definition and, consequently, a constructive process to be explored. In this way, there is numerous avenues that can be studied regarding self-defining goals and respective indicators.

Future work has several possibilities to address. Researches can evaluate the extent to which those helping behaviors embody self-symbolizing needs and social identifications. One of the alternatives is the approach of licensing theory to better understand these effects. Different from self-completion theory, licensing comprises a more explicit and rational mechanism that can boost someone's self-concept in a first moment, which in turn can liberate 
the person from engaging in posterior behaviors. Furthermore, the satiation effect of selfcompletion that we propose in this article happens in a social identity context. Next studies can investigate these effects in other domains, such as self-consistency theory. An additional opportunity of research is to include personal traits and customers' characteristics that can affect these mechanisms. Self-esteem, self-efficacy, empathy, and private and public selfconsciousness may be relevant factors to understand how and why the effects occur. Another way to think about the relationship of CSR on $\mathrm{CCB}$ is providing a halo effect to extend the feeling towards CSR endorsement beyond the direct relationship between consumercompany, including other customers and stakeholders. We also speculate that the company CSR activity may play a role in the interaction. CRM, the activity used in Study 1, embeds self-identity and demands some cognitive effort from customers. Next studies could examine the moderating role of choice and how deliberately selecting a program may affect the following interactions among fellow customers. Studies to generalize our results, such as manipulating entitativity (e.g., Crawford, Sherman, \& Hamilton, 2002) or using fictional firms, may also be conducted.

Our findings have relevant implications to services industry. Since citizenship behaviors help to develop a good climate service, customer satisfaction, loyalty, and corporate reputation, companies should invest on activities that provide an entitative group perception to their customers (e.g., virtual communities, activities in special occasions, etc.). Additional measures that aim to mitigate adverse effects of CSR may assist companies to have more positive outputs considering CCB. Actions promoting customer-company identification may also help to extend the help towards other customers of the firm. Other types of CSR (e.g., philanthropy or ethical business practices) can trigger different social-identity mechanisms among members. Besides, marketers should also consider aspects of CSR initiatives, such as periodicity, intensity, and social projection that may be connected to the discussed issues regarding self-completion (i.e., impatience and overextension). 


\section{CONCLUSION}

This dissertation offered several contributions to the marketing field. In Chapter 2, we analyzed existing CCB studies, building connections among them, and identifying gaps that future researches could address. In this sense, we discussed possibilities of studies that encompasses the theoretical and methodological field of citizenship behaviors. Besides social exchange theory and social identity theory, supporting theories are still understudied and represent important sources of contributions (e.g., empathy, self-concept, and self-congruency theories). Most importantly, a considerable amount of papers doesn't position their contributions to the theory, what may interfere in the building theory process. Research has focused predominantly on quantitative methods and analysis, when feelings, emotions, and motivations involved in such activities may require a more interpretative approach. Other methods may (or even combining methods) provide new perspectives about the same phenomenon. Also, there is a latent necessity to approach employees' feelings towards CCB and to investigate cultural differences regarding $\mathrm{CCB}$ (e.g., individualist versus collectivist or interdependent versus independent). Divergence between types of CCB may help to build ideas to promote cooperation in the service encounter, besides promoting competitive advantage to the firm.

In Chapter 3, we investigated how customers perceive value on performing CCB. Building on the previous theorizing from Holbrook $(1994,1999)$ and Clary et al. (1998), we integrated emerging patterns of motivations to different types of values and proposed a framework to analyze what encourages customers to perform discretionary behaviors towards the company and other customers. Considering dichotomies of self-oriented versus otheroriented and extrinsic versus intrinsic values, we also discussed the dynamics of values and particularities of specific dimensions of CCB (i.e., helping other customers, feedback, recommendation, and tolerance). Helping the company, employees, and other customers is not a straightforward process with direct results. Although $\mathrm{CCB}$ has been associated with positive antecedents and outcomes (e.g., Groth, 2005, Bove et al., 2009), customers may engage in displays of tolerance to cope with their protective function or feelings of impotence towards the service experience (Clary et al., 1998).

These behaviors are beneficial to the firm in the short term but may harm customercompany relationship due to its passive and reactive nature. Since the variance of service quality may be an issue, marketers could work with cues connected to ego-related perceived values to improve tolerance, feedback, and help during the service encounter (e.g., 
communications signaling empowerment). Managers should also develop communications channels at different levels in the organization and institutionalize more points of contact with customers to discourage undesirable and incoherent behaviors from other customers and employees. Future studies may explore the value of CCB by helped customers and employees of the firm. CCB literature is still concentrated on customers who help rather than the ones helped. Other types of citizenship behaviors, such as advocacy, cooperation, and facilitation may comprehend different perceived values and sources of motivation than those explored in this study.

In Chapter 4, we analyzed how a company CSR activities can influence helping behaviors among their customers. Based on two studies, we demonstrated that when participants were faced with a previous opportunity to satiate self-defining goals through CSR, they had a reduced propensity to help other customers (i.e., citizenship behaviors). Further, we also suggested that these findings are part of a phenomenon called overextension and impatience that attenuate the willingness to help in a second opportunity (Wicklund \& Gollwitzer, 2013). Ego depletion, that refers to the idea of completing a task which produces a temporary reduction of self-control to perform a second one, provides a subsidiary explanation to the observed results (Wicklund \& Gollwitzer, 1981).

Additional measures that aim to mitigate adverse effects of CSR may assist companies to have more positive outputs considering CCB. Actions promoting customer-company identification may also help to extend the help towards other customers of the firm. Other types of CSR (e.g., philanthropy or ethical business practices) can trigger different socialidentity mechanisms among members. Besides, marketers should also consider aspects of CSR initiatives, such as periodicity, intensity, and social projection that may be connected to the discussed issues regarding self-completion (i.e., impatience and overextension). 


\section{REFERENCES}

Aaker, J. L. (1999). The malleable self: The role of self-expression in persuasion. Journal of marketing research, 45-57.

Adjei, M. T., Noble, S. M., \& Noble, C. H. (2010). The influence of C2C communications in online brand communities on customer purchase behavior. Journal of the Academy of Marketing Science, 38(5), 634-653.

Ahearne, M., Bhattacharya, C. B., \& Gruen, T. (2005). Antecedents and consequences of customer-company identification: Expanding the role of relationship marketing. Journal of applied psychology, 90(3), 574.

Algesheimer, R., Dholakia, U. M., \& Herrmann, A. (2005). The social influence of brand community: Evidence from European car clubs. Journal of marketing, 69(3), 19-34.

Anaza, N. A. (2014). Personality antecedents of customer citizenship behaviors in online shopping situations. Psychology \& Marketing, 31(4), 251-263.

Anaza, N., \& Zhao, J. (2013). Encounter-based antecedents of e-customer citizenship behaviors. Journal of Services Marketing, 27(2), 130-140.

Balaji, M. S. (2014). Managing customer citizenship behavior: A relationship perspective. Journal of Strategic Marketing, 22(3), 222-239.

Barbuto, J. E. (2001). Understanding and applying an integrative taxonomy of motivation sources to professional and personal settings. Journal of Management Education, 25(6),713-725.

Bar-Tal, D. (1976). Prosocial behavior: Theory and research. 
Bartikowski, B., \& Walsh, G. (2011). Investigating mediators between corporate reputation and customer citizenship behaviors. Journal of Business Research, 64(1), 39-44.

Batson, C. D., \& Shaw, L. L. (1991). Evidence for altruism: Toward a pluralism of prosocial motives. Psychological inquiry, 2(2), 107-122.

Belk, R. W. (1988). Possessions and the extended self. Journal of consumer research, 15(2), 139-168.

Belk, R. W., Wallendorf, M., \& Sherry Jr, J. F. (1989). The sacred and the profane in consumer behavior: Theodicy on the odyssey. Journal of consumer research, 16(1), 1-38.

Bellezza, S., Gino, F., \& Keinan, A. (2013). The red sneakers effect: Inferring status and competence from signals of nonconformity. Journal of consumer research, 41(1), 35-54.

Benabou, R., \& Tirole, J. (2003). Intrinsic and extrinsic motivation. The review of economic studies, 70(3), 489-520.

Berlyne, D. E. (1966). Conditions of prequestioning and retention of meaningful material. Journal of Educational Psychology, 57, 128-132.

Bettencourt, L. A. (1997). Customer voluntary performance: Customers as partners in service delivery. Journal of retailing, 73(3), 383-406.

Bhattacharya, C. B., \& Sen, S. (2004). Doing better at doing good: When, why, and how consumers respond to corporate social initiatives. California management review, 47(1), 9-24.

Bitner, M. J. (1992). Servicescapes: The impact of physical surroundings on customers and employees. The Journal of Marketing, 57-71. 
Bitner, M. J., Booms, B. H., \& Mohr, L. A. (1994). Critical service encounters: The employee's viewpoint. The journal of marketing, 95-106.

Bitner, M. J., Booms, B. H., \& Tetreault, M. S. (1990). The service encounter: diagnosing favorable and unfavorable incidents. The Journal of Marketing, 71-84.

Bitner, M. J., Brown, S. W., \& Meuter, M. L. (2000). Technology infusion in service encounters. Journal of the Academy of marketing Science, 28(1), 138-149.

Black, H. G., H. Vincent, L., \& J. Skinner, S. (2014). Customers helping customers: payoffs for linking customers. Journal of Services Marketing, 28(5), 391-401.

Bourdieu, P. (1986). The forms of capital. In J. G. Richardson (Ed.), Handbook of theory and research for the sociology of education: 241-258. New York: Greenwood.

Bove, L. L., Pervan, S. J., Beatty, S. E., \& Shiu, E. (2009). Service worker role in encouraging customer organizational citizenship behaviors. Journal of Business Research, 62(7), 698-705.

Bowen, D. E., Schneider, B., \& Kim, S. S. (2000). Shaping service cultures through strategic human resource management. Handbook of services marketing and management, 439-454.

Breunig, K. J., \& Christoffersen, L. (2016). If $x$ then why? Comparative analysis using critical incidents technique. Journal of Business Research, 69(11), 5141-5146.

Butterfield, L. D., Borgen, W. A., Amundson, N. E., \& Maglio, A. S. T. (2005). Fifty years of the critical incident technique: 1954-2004 and beyond. Qualitative research, 5(4), 475-497.

Burmann, C., Jost-Benz, M., \& Riley, N. (2009). Towards an identity-based brand equity model. Journal of Business Research, 62(3), 390-397.

Buss, A. H. (1980). Self-consciousness and social anxiety. Freeman. 
Campbell, D. T. (1958). Common fate, similarity, and other indices of the status of aggregates of persons as social entities. Systems research and behavioral science, 3(1), 14-25.

Choi, L., \& Lotz, S. (2016). Motivations leading to customer citizenship behavior in services: scale development and validation. Journal of Consumer Marketing, 33(7), 539-551.

Cialdini, R. B., \& Goldstein, N. J. (2004). Social influence: Compliance and conformity. Annu. Rev. Psychol., 55, 591-621.

Clary, G., Ridge, R., Stukas, A., Snyder, M., Copeland, J., Haugen, J., \& Miene, P. (1998). Understanding and assessing the motivation of volunteers: A functional approach. Journal of Personality \& Social Psychology, 74, 1516-1530. s[s]

Clary, G., \& Snyder, M. (1999). The motivations to volunteer: Theoretical and practical considerations. Current directions in psychological science, 8(5), 156-159.

Clary, G., Snyder, M., \& Stukas, A. (1996). Volunteers' motivation: Findings from a national survey. Nonprofit and Voluntary Sector Quarterly, 25, 485-505.

Cova, B., \& Dalli, D. (2009). Working consumers: the next step in marketing theory?. Marketing theory, 9(3), 315-339.

Cova, B., Pace, S., \& Skålén, P. (2015). Brand volunteering: Value co-creation with unpaid consumers. Marketing Theory, 15(4), 465-485.

Crawford, M. T., Sherman, S. J., \& Hamilton, D. L. (2002). Perceived entitativity, stereotype formation, and the interchangeability of group members. Journal of personality and social psychology, 83(5), 1076.

Crossan, M. M., \& Apaydin, M. (2010). A multi-dimensional framework of organizational innovation: A systematic review of the literature. Journal of management studies, 47(6), 1154-1191. 
Curth, S., Uhrich, S., \& Benkenstein, M. (2014). How commitment to fellow customers affects the customer-firm relationship and customer citizenship behavior. Journal of Services Marketing, 28(2), 147-158.

De Waal, F. B. (2008). Putting the altruism back into altruism: the evolution of empathy. Annu. Rev. Psychol., 59, 279-300.

Dobson, A. J., \& Barnett, A. (2008). An introduction to generalized linear models. CRC press.

Dong, B., Evans, K. R., \& Zou, S. (2008). The effects of customer participation in cocreated service recovery. Journal of the academy of marketing science, 36(1), 123-137.

Edvardsson, B., Tronvoll, B., \& Gruber, T. (2011). Expanding understanding of service exchange and value co-creation: a social construction approach. Journal of the Academy of Marketing Science, 39(2), 327-339.

Effron, D. A., \& Knowles, E. D. (2015). Entitativity and intergroup bias: How belonging to a cohesive group allows people to express their prejudices. Journal of personality and social psychology, 108(2), 234.

Eisingerich, A. B., Auh, S., \& Merlo, O. (2014). Acta non verba? The role of customer participation and word of mouth in the relationship between service firms' customer satisfaction and sales performance. Journal of Service Research, 17(1), 40-53.

Finkelstein, M. A., \& Brannick, M. T. (2007). Applying theories of institutional helping to informal volunteering: Motives, role identity, and prosocial personality. Social Behavior and Personality: an international journal, 35(1), 101-114.

Flanagan, J. C. (1954). The critical incident technique. Psychological bulletin, 51(4), 327-358. 
Gallarza, M. G., \& Saura, I. G. (2006). Value dimensions, perceived value, satisfaction and loyalty: an investigation of university students' travel behaviour. Tourism management, 27(3), 437-452.

Gardner, M. P. (1985). Mood states and consumer behavior: A critical review. Journal of Consumer research, 12(3), 281-300.

Garma, R., \& Bove, L. L. (2011). Contributing to well-being: customer citizenship behaviors directed to service personnel. Journal of Strategic Marketing, 19(7), 633-649.

Giebelhausen, M., Chun, H. H., Cronin Jr, J. J., \& Hult, G. T. M. (2016). Adjusting the warm-glow thermostat: How incentivizing participation in voluntary green programs moderates their impact on service satisfaction. Journal of Marketing, 80(4), 56-71.

Gilde, C., Pace, S., Pervan, S. J., \& Strong, C. (2011). Examining the boundary conditions of customer citizenship behaviour: a focus on consumption ritual. Journal of strategic Marketing, 19(7), 619-631.

Goldstein, N. J., Cialdini, R. B., \& Griskevicius, V. (2008). A room with a viewpoint: Using social norms to motivate environmental conservation in hotels. Journal of consumer Research, 35(3), 472-482.

Gollwitzer, P. M., \& Sheeran, P. (2006). Implementation intentions and goal achievement: A meta-analysis of effects and processes. Advances in experimental social psychology, 38, 69-119.

Gouthier, M., \& Schmid, S. (2003). Customers and customer relationships in service firms: The perspective of the resource-based view. Marketing Theory, 3(1), 119143. 
Greer, D. A. (2015). Defective co-creation: developing a typology of consumer dysfunction in professional services. European Journal of Marketing, 49(1/2), 238-261.

Gremler, D. D. (2004). The critical incident technique in service research. Journal of service research, 7(1), 65-89.

Grönroos, C. (1984). A service quality model and its marketing implications. European Journal of marketing, 18(4), 36-44.

Groth, M. (2005). Customers as good soldiers: Examining citizenship behaviors in internet service deliveries. Journal of management, 31(1), 7-27.

Grove, S. J., \& Fisk, R. P. (1997). The impact of other customers on service experiences: a critical incident examination of "getting along". Journal of retailing, 73(1), 6385.

Habel, J., Schons, L. M., Alavi, S., \& Wieseke, J. (2016). Warm glow or extra charge? The ambivalent effect of corporate social responsibility activities on customers' perceived price fairness. Journal of Marketing, 80(1), 84-105.

Hamilton, W. D. (1964). The genetical evolution of social behaviour. II. Journal of theoretical biology, 7(1), 17-52.

Hamilton, D. L., Sherman, S. J., \& Lickel, B. (1998). Perceiving social groups: The importance of the entitativity continuum. In C. Sedikides, J. Schopler, \& C. A. Insko (Eds.), Intergroup cognition and intergroup behavior (pp. 47-74). Mahwah, NJ, US: Lawrence Erlbaum Associates Publishers.

Hansen, J., Kutzner, F., \& Wänke, M. (2012). Money and thinking: Reminders of money trigger abstract construal and shape consumer judgments. Journal of Consumer Research, 39(6), 1154-1166. 
Harris, L. C., \& Daunt, K. (2013). Managing customer misbehavior: challenges and strategies. Journal of Services Marketing, 27(4), 281-293.

Hayes, A. F. (2013). Introduction to mediation, moderation, and conditional process analysis: A regression-based approach. Guilford Publications.

Heskett, J., Sasser, W. E., \& Schlesinger, L. A. (1997). The Service Profit Chain: How Leading Companies Link Profit and Growth to Loyalty, Satisfaction, and Value.

Hirschman, E. C., \& Holbrook, M. B. (1982). Hedonic consumption: emerging concepts, methods and propositions. The Journal of Marketing, 92-101.

Hoffman, K. Douglas, Scott W. Kelley, \& Beth C. Chung (2003), “A CIT Investigation of Servicescape Failures and Associated Recovery Strategies," Journal of Services Marketing, 17 (4), 322-40.

Hogg, M. A., Sherman, D. K., Dierselhuis, J., Maitner, A. T., \& Moffitt, G. (2007). Uncertainty, entitativity, and group identification. Journal of experimental social psychology, 43(1), 135-142.

Holbrook, M. B. (1994). The nature of customer value: an axiology of services in the consumption experience. Service quality: New directions in theory and practice, $21,21-71$.

Holbrook, M. B. (1996). Special session summary customer value C a framework for analysis and research. ACR North American Advances.

Holbrook, M. B. (Ed.). (1999). Consumer value: a framework for analysis and research. Psychology Press.

Hong, J. and Chang, H.H., 2015. "I" follow my heart and "We" rely on reasons: The impact of self-construal on reliance on feelings versus reasons in decision making. Journal of Consumer Research, 41(6), pp.1392-1411. 
Izuma, K., Saito, D. N., \& Sadato, N. (2010). Processing of the incentive for social approval in the ventral striatum during charitable donation. Journal of cognitive neuroscience, 22(4), 621-631.

Johnson, Z., Massiah, C., \& Allan, J. (2013). Community identification increases consumer-to-consumer helping, but not always. Journal of Consumer Marketing, 30(2), 121-129.

Johnson, J. W., \& Rapp, A. (2010). A more comprehensive understanding and measure of customer helping behavior. Journal of Business Research, 63(8), 787-792.

Johnson, M. D., \& Selnes, F. (2004). Customer portfolio management: Toward a dynamic theory of exchange relationships. Journal of Marketing, 68(2), 1-17.

Joshi, A. W., \& Sharma, S. (2004). Customer knowledge development: antecedents and impact on new product performance. Journal of marketing, 68(4), 47-59.

Jung, J. H., Yoo, J. J., \& Arnold, T. J. (2017). Service Climate as a Moderator of the Effects of Customer-to-Customer Interactions on Customer Support and Service Quality. Journal of Service Research, 20(4), 426-440.

Karaosmanoglu, E., Altinigne, N., \& Isiksal, D. G. (2016). CSR motivation and customer extra-role behavior: Moderation of ethical corporate identity. Journal of Business Research, 69(10), 4161-4167.

Katz, D. (1960). The functional approach to the study of attitudes. Public opinion quarterly, 24(2), 163-204.

Keatinge, D. (2002). Versatility and flexibility: Attributes of the critical incident technique in nursing research. Nursing \& Health Sciences, 4(1-2), 33-39.

Keaveney, Susan M. (1995), “Customer Switching Behavior in Service Industries: An Exploratory Study,” Journal of Marketing, 59 (April), 71-82. 
Kim, H. S., \& Choi, B. (2016). The effects of three customer-to-customer interaction quality types on customer experience quality and citizenship behavior in mass service settings. Journal of Services Marketing, 30(4), 384-397.

Krebs, D. L. (1970). Altruism: An examination of the concept and a review of the literature. Psychological bulletin, 73(4), 258.

Kruglanski, A. W., \& Webster, D. M. (1991). Group members' reactions to opinion deviates and conformists at varying degrees of proximity to decision deadline and of environmental noise. Journal of personality and social psychology, 61(2), 212.

Lam, S. K., Ahearne, M., Hu, Y., \& Schillewaert, N. (2010). Resistance to brand switching when a radically new brand is introduced: A social identity theory perspective. Journal of Marketing, 74(6), 128-146.

Leary, M. R., \& Kowalski, R. M. (1990). Impression management: A literature review and two-component model. Psychological bulletin, 107(1), 34.

Leclerc, F., Schmitt, B. H., \& Dube, L. (1995). Waiting time and decision making: Is time like money?. Journal of Consumer Research, 22(1), 110-119.

Lengnick-Hall, C. A., Claycomb, V., \& Inks, L. W. (2000). From recipient to contributor: examining customer roles and experienced outcomes. European Journal of Marketing, 34(3/4), 359-383.

Leroi-Werelds, S., Streukens, S., Brady, M. K., \& Swinnen, G. (2014). Assessing the value of commonly used methods for measuring customer value: A multi-setting empirical study. Journal of the Academy of Marketing Science, 42(4), 430-451.

Lewis, C. I. (1946), An Analysis of Knowledge and Valuation, La Salle, IL: Open Court.

Lewis, B. R. \& Spyrakopoulos, S. (2001), "Service Failures and Recovery in Retail Banking: The Customers' Perspective,” International Journal of Bank Marketing, $19(1), 37-47$. sep 
Lichtenstein, D. R., Drumwright, M. E., \& Braig, B. M. (2004). The effect of corporate social responsibility on customer donations to corporate-supported nonprofits. Journal of marketing, 68(4), 16-32.

Lickel, B., Hamilton, D. L., Wieczorkowska, G., Lewis, A., Sherman, S. J., \& Uhles, A. N. (2000). Varieties of groups and the perception of group entitativity. Journal of personality and social psychology, 78(2), 223.

Lii, Y. S., \& Lee, M. (2012). Doing right leads to doing well: When the type of CSR and reputation interact to affect consumer evaluations of the firm. Journal of business ethics, 105(1), 69-81.

Liu, W., \& Aaker, J. (2008). The happiness of giving: The time-ask effect. Journal of consumer research, 35(3), 543-557.

Luchs, M. G., Naylor, R. W., Irwin, J. R., \& Raghunathan, R. (2010). The sustainability liability: Potential negative effects of ethicality on product preference. Journal of Marketing, 74(5), 18-31.

Luo, X., \& Bhattacharya, C. B. (2006). Corporate social responsibility, customer satisfaction, and market value. Journal of marketing, 70(4), 1-18.

Lusch, R. F., \& Vargo, S. L. (2006). The service-dominant logic of marketing: Reactions, reflections, and refinements. Marketing Theory, 6(3), 281-288.

McCullagh, P., \& Nelder, J. A. (1989). Binary data. In Generalized linear models (pp. 98-148). Springer US.

Malhotra, N. K. (1996). The impact of the academy of marketing science on marketing scholarship: An analysis of the research published inJAMS. Journal of the Academy of Marketing Science, 24(4), 291. 
Matten, D., \& Moon, J. (2008). "Implicit" and "explicit" CSR: A conceptual framework for a comparative understanding of corporate social responsibility. Academy of management Review, 33(2), 404-424.

Marin, L., \& Ruiz, S. (2007). “I need you too!" Corporate identity attractiveness for consumers and the role of social responsibility. Journal of business ethics, 71(3), 245-260.

Marin, L., Ruiz, S., \& Rubio, A. (2009). The role of identity salience in the effects of corporate social responsibility on consumer behavior. Journal of Business Ethics, $84,65-78$.

Maslow, A. H. (1968). Toward a psychology of being ( $2^{\text {nd }}$ ed.). New York: Van Nostrand Reinhold.

Massi Lindsey, L. L. (2005). Anticipated guilt as behavioral motivation: An examination of appeals to help unknown others through bone marrow donation. Human Communication Research, 31(4), 453-481.

Mathwick, C., Malhotra, N.K. \& Rigdon, E. (2002) The Effect of Dynamic Retail Experiences on Experiential Perceptions of Value: An Internet and Catalog Comparison, Journal of Retailing 78(1), 51-60.

Matthews, A. M. (1991). If I think about money so much, why can't I figure it out?: understanding and overcoming your money complex. New York: Summit.

McConnell, A. R., Sherman, S. J., \& Hamilton, D. L. (1997). Target entitativity: Implications for information processing about individual and group targets. Journal of personality and social psychology, 72(4), 750.

Meuter, M. L., Ostrom, A. L., Roundtree, R. I., \& Bitner, M. J. (2000). Self-service technologies: understanding customer satisfaction with technology-based service encounters. Journal of marketing, 64(3), 50-64.

Miles, M. B., \& Huberman, A. M. (1994). Qualitative data analysis: An expanded sourcebook. sage. 
Moe, W. W., \& Trusov, M. (2011). The value of social dynamics in online product ratings forums. Journal of Marketing Research, 48(3), 444-456.

Mogilner, C., \& Aaker, J. (2009). "The time vs. money effect": Shifting product attitudes and decisions through personal connection. Journal of Consumer Research, 36(2), 277-291.

Molm, L. D. (2010). The structure of reciprocity. Social psychology quarterly, 73(2), 119-131.

Muniz, A. M., \& O'guinn, T. C. (2001). Brand community. Journal of consumer research, 27(4), 412-432.

Muraven, M., \& Baumeister, R. F. (2000). Self-regulation and depletion of limited resources: Does self-control resemble a muscle?. Psychological bulletin, 126(2), 247

Nguyen, H., Groth, M., Walsh, G., \& Hennig-Thurau, T. (2014). The impact of service scripts on customer citizenship behavior and the moderating role of employee customer orientation. Psychology \& Marketing, 31(12), 1096-1109.

Organ, D. W. (1988). Organizational citizenship behavior: The good soldier syndrome. Lexington, MA: Lexington Books.

Oyedele, A., \& Simpson, P. M. (2011). Understanding motives of consumers who help. Journal of strategic marketing, 19(7), 575-589.

Parker, C., \& Ward, P. (2000). An analysis of role adoptions and scripts during customer-to-customer encounters. European Journal of Marketing, 34(3/4), 341359.

Parasuraman, A., Berry, L. L., \& Zeithaml, V. A. (1991). Refinement and reassessment of the SERVQUAL scale. Journal of retailing, 67(4), 420. 
Paxton, P. (1999). Is social capital declining in the United States? A multiple indicator assessment. American Journal of sociology, 105(1), 88-127.

Peattie, S., \& Peattie, K. (2003). Ready to fly solo? Reducing social marketing's dependence on commercial marketing theory. Marketing theory, 3(3), 365-385.

Peloza, J., \& Shang, J. (2011). How can corporate social responsibility activities create value for stakeholders? A systematic review. Journal of the academy of Marketing Science, 39(1), 117-135.

Pérez, A., \& Del Bosque, I. R. (2015). An integrative framework to understand how CSR affects customer loyalty through identification, emotions and satisfaction. Journal of Business Ethics, 129(3), 571-584.

Perry, R. B. (1954), Realms of Value, Cambridge, MA: Harvard University Press

Pervan, S. J., \& Bove, L. L. (2011). The engagement of customers beyond their expected roles.

Pervin, L. A. (Ed.). (2015). Goal concepts in personality and social psychology. Psychology Press.

Pirsch, J., Gupta, S., \& Grau, S. L. (2007). A framework for understanding corporate social responsibility programs as a continuum: An exploratory study. Journal of business ethics, 70(2), 125-140.

Podsakoff, N. P., Whiting, S. W., Podsakoff, P. M., \& Blume, B. D. (2009). Individualand organizational-level conse- quences of organizational citizenship behaviors: A meta- analysis. Journal of Applied Psychology, 94, 122-141.

Portes, A. (1998). Social capital: Its origins and applications in modern sociology. Annual review of sociology, 24(1), 1-24. 
Ramasamy, B., Yeung, M. C. H., \& Au, A. K. M. (2010). Consumer support for corporate social responsibility (CSR): The role of religion and values. Journal of Business Ethics, 91, 61-72.

Revilla-Camacho, M. Á., Vega-Vázquez, M., \& Cossío-Silva, F. J. (2015). Customer participation and citizenship behavior effects on turnover intention. Journal of business research, 68(7), 1607-1611.

Revilla-Camacho, M. Á., Vega-Vázquez, M., \& Cossío-Silva, F. J. (2017). Exploring the customer's intention to switch firms: The role of customer-related antecedents. Psychology \& Marketing, 34(11), 1039-1049.

Roggeveen, A. L., Tsiros, M., \& Grewal, D. (2012). Understanding the co-creation effect: when does collaborating with customers provide a lift to service recovery?. Journal of the Academy of Marketing Science, 40(6), 771-790.

Ros, M., Schwartz, S. H., \& Surkiss, S. (1999). Basic individual values, work values, and the meaning of work. Applied psychology, 48(1), 49-71.

Rosenbaum, M. S., \& Martin, D. (2012). Wearing community: why customers purchase a service firm's logo products. Journal of Services Marketing, 26(5), 310-321.

Rosenbaum, M. S., \& Massiah, C. A. (2007). When customers receive support from other customers: Exploring the influence of intercustomer social support on customer voluntary performance. Journal of Service Research, 9(3), 257-270.

Ryan, R. M., \& Deci, E. L. (2000). Intrinsic and extrinsic motivations: Classic definitions and new directions. Contemporary educational psychology, 25(1), 5467.

Rydell, R. J., \& McConnell, A. R. (2005). Perceptions of entitativity and attitude change. Personality and Social Psychology Bulletin, 31(1), 99-110. 
Sánchez-Fernández, R., \& Iniesta-Bonillo, M. Á. (2007). The concept of perceived value: a systematic review of the research. Marketing theory, 7(4), 427-451.

Sen, S., \& Bhattacharya, C. B. (2001). Does doing good always lead to doing better? Consumer reactions to corporate social responsibility. Journal of marketing Research, 38(2), 225-243.

Shavitt, S. (1990). The role of attitude objects in attitude functions. Journal of Experimental Social Psychology, 26(2), 124-148.

Simpson, B., \& Willer, R. (2008). Altruism and indirect reciprocity: The interaction of person and situation in prosocial behavior. Social Psychology Quarterly, 71(1), $37-52$.

Smith, R. W., Faro, D., \& Burson, K. A. (2012). More for the many: The influence of entitativity on charitable giving. Journal of Consumer Research, 39(5), 961-976.

Snyder, M. (1992). Motivational foundations of behavioral confirmation. In Advances in experimental social psychology(Vol. 25, pp. 67-114). Academic Press.

Snyder, M. (1993). Basic research and practical problems: The promise of a" functional" personality and social psychology. Personality and Social Psychology Bulletin, 19(3), 251-264.

Stets, J. E., \& Burke, P. J. (2000). Identity theory and social identity theory. Social psychology quarterly, 224-237.

Steenkamp, J. B. E., \& Geyskens, I. (2006). How country characteristics affect the perceived value of web sites. Journal of marketing, 70(3), 136-150.

Sylwester, K., \& Roberts, G. (2013). Reputation-based partner choice is an effective alternative to indirect reciprocity in solving social dilemmas. Evolution and Human Behavior, 34(3), 201-206. 
Tajfel, H., \& Turner, J. C. (1979). The Social Identity Theory of Intergroup Behavior, in Psychology of Intergroup Relations, Stephen Worchel and William G. Austin, eds. Chicago: NelsonHall, 33-47.

Taylor, S. A., \& Baker, T. L. (1994). An assessment of the relationship between service quality and customer satisfaction in the formation of consumers' purchase intentions. Journal of retailing, 70(2), 163-178.

Thompson, S. A., Kim, M., \& Smith, K. M. (2016). Community Participation and Consumer-to-Consumer Helping: Does Participation in Third Party-Hosted Communities Reduce One's Likelihood of Helping?. Journal of Marketing Research, 53(2), 280-295.

Tomasello, M., \& Vaish, A. (2013). Origins of human cooperation and morality. Annual review of psychology, 64, 231-255.

Tranfield, D., Denyer, D., \& Smart, P. (2003). Towards a methodology for developing evidence-informed management knowledge by means of systematic review. British journal of management, 14(3), 207-222.

Trivers, R. L. (1971). The evolution of reciprocal altruism. The Quarterly review of biology, 46(1), 35-57.

Vallerand, R. J. (1997). Toward a hierarchical model of intrinsic and extrinsic motivation. In Advances in experimental social psychology (Vol. 29, pp. 271360). Academic Press.

Vargo, S. L., \& Lusch, R. F. (2004). Evolving to a new dominant logic for marketing. Journal of marketing, 68(1), 1-17.

Vargo, S. L., \& Lusch, R. F. (2008). Service-dominant logic: continuing the evolution. Journal of the Academy of marketing Science, 36(1), 1-10.

Verma, Harsh V. (2003), "Customer Outrage and Delight," Journal of Services 
Research, 3 (April-September), 119-33, sh:

Wang, Y. B., \& Ho, C. W. (2017). No Money? No Problem! The Value of Sustainability: Social Capital Drives the Relationship among Customer Identification and Citizenship Behavior in Sharing Economy. Sustainability, 9(8), 1400.

White, R. W. (1959). Motivation reconsidered: The concept of competence. Psychological review, 66(5), 297.

Wicklund, R. A., \& Gollwitzer, P. M. (2013). Symbolic self completion. Routledge.

Wicklund, R. A., \& Gollwitzer, P. M. (1981). Symbolic self-completion, attempted influence, and self-deprecation. Basic and applied social psychology, 2(2), 89114.

Xie, L., Poon, P., \& Zhang, W. (2017). Brand experience and customer citizenship behavior: the role of brand relationship quality. Journal of Consumer Marketing, 34(3).

Yi, Y., \& Gong, T. (2008). The effects of customer justice perception and affect on customer citizenship behavior and customer dysfunctional behavior. Industrial Marketing Management, 37(7), 767-783.

Yi, Y., \& Gong, T. (2013). Customer value co-creation behavior: Scale development and validation. Journal of Business Research, 66(9), 1279-1284.

Yi, Y., Gong, T., \& Lee, H. (2013). The impact of other customers on customer citizenship behavior. Psychology \& Marketing, 30(4), 341-356.

Yi, Y., Nataraajan, R., \& Gong, T. (2011). Customer participation and citizenship behavioral influences on employee performance, satisfaction, commitment, and turnover intention. Journal of Business Research, 64(1), 87-95. 
Yzerbyt, V. Y., Rogier, A., \& Fiske, S. T. (1998). Group entitativity and social attribution: On translating situational constraints into stereotypes. Personality and Social Psychology Bulletin, 24(10), 1089-1103.

Zaglia, M. E. (2013). Brand communities embedded in social networks. Journal of business research, 66(2), 216-223.

Zainuddin, N., Russell-Bennett, R., \& Previte, J. (2013). The value of health and wellbeing: an empirical model of value creation in social marketing. European Journal of Marketing, 47(9), 1504-1524.

Zhang, J., Beatty, S. E., \& Mothersbaugh, D. (2010). A CIT investigation of other customers' influence in services. Journal of Services Marketing, 24(5), 389-399.

Zhou, X., Vohs, K. D., \& Baumeister, R. F. (2009). The symbolic power of money: Reminders of money alter social distress and physical pain. Psychological Science, 20(6), 700-706. 


\title{
APPENDIX
}

\section{APPENDIX A - MANIPULATIONS OF EXPERIMENT 1}

Together we are going to do a lot of good!

\author{
Microsoft Office + TEALS (Technology Education and Literacy in Schools)
}

- Premium versions of apps you know like Word, Excel, PowerPoint, Outlook, Access;

- New and exclusive features released every month;

- Work across multiples devices (1 PC/MAC, 1 tablet and 1 phone);

- 3 TB of cloud storage:

- adherence to " 1 subscription $=1$ tablet" campaign*.

* For each subscription, Microsoft will be giving 1 (one) tablet to TEALS (Technology Education and Literacy in Schools). In the U.S., there will be 1.4 million Computer Science-related jobs by

2020. For American youth, this means an unfortunate mismatch between education and

opportunity that we must solve by bringing together resources from across the CS industry.

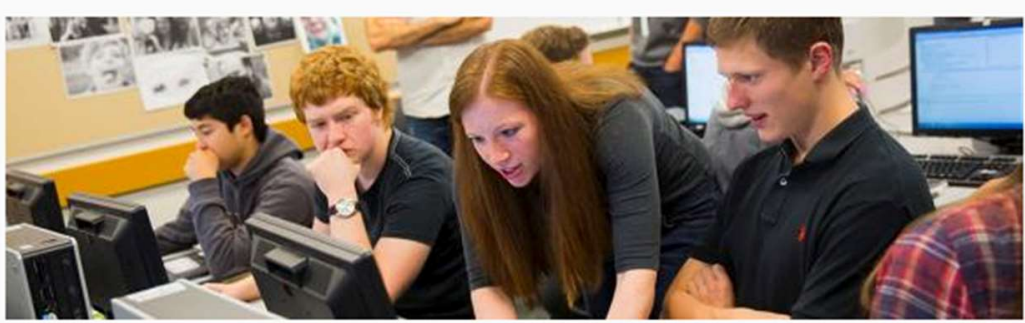

Together we are going to do a lot of good!

Microsoft Office + Boys \& Girls Clubs of America

- Premium versions of apps you know like Word, Excel, PowerPoint, Outlook, Access;

- New and exclusive features released every month;

- Work across multiples devices (1 PC/MAC, 1 tablet and 1 phone);

- 3 TB of cloud storage;

- adherence to " 1 subscription $=1$ tablet" campaign*

* For each subscription, Microsoft will be giving 1 (one) tablet for Boys \& Girls Clubs of America (BGCA). While BGCA provides after-school enrichment for all children, nearly $60 \%$ of its members qualify for free-or-reduced-cost lunch, a standard measure of poverty in the US.

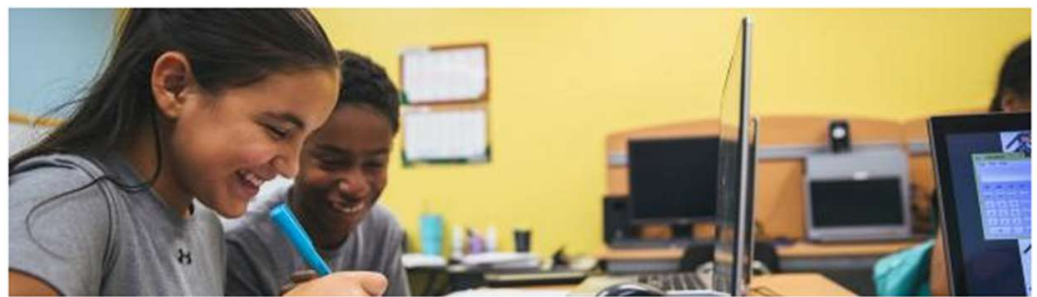




\section{Microsoft Office + Math Works}

- Premium versions of apps you know like Word, Excel, PowerPoint, Outlook, Access;

- New and exclusive features released every month;

- Work across multiples devices (1 PC/MAC, 1 tablet and 1 phone);

- 3 TB of cloud storage; and

- Exclusive app Math Works, new app that recognizes, solves and graphs handwritten equations.

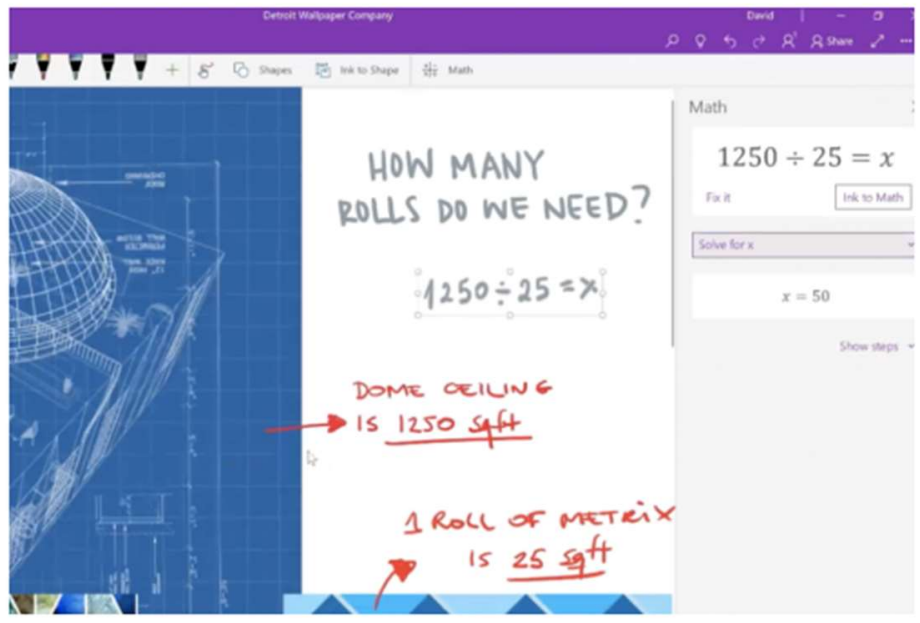

\section{Microsoft Office + Microsoft Groups}

- Premium versions of apps you know like Word, Excel, PowerPoint, Outlook, Access;

- New features released every month;

- Work across multiples devices (1 PC/MAC, 1 tablet and 1 phone);

- 3 TB of cloud storage; and

- Exclusive app Microsoft Groups, new hub for teamwork that brings people, conversations, and content together in real time.

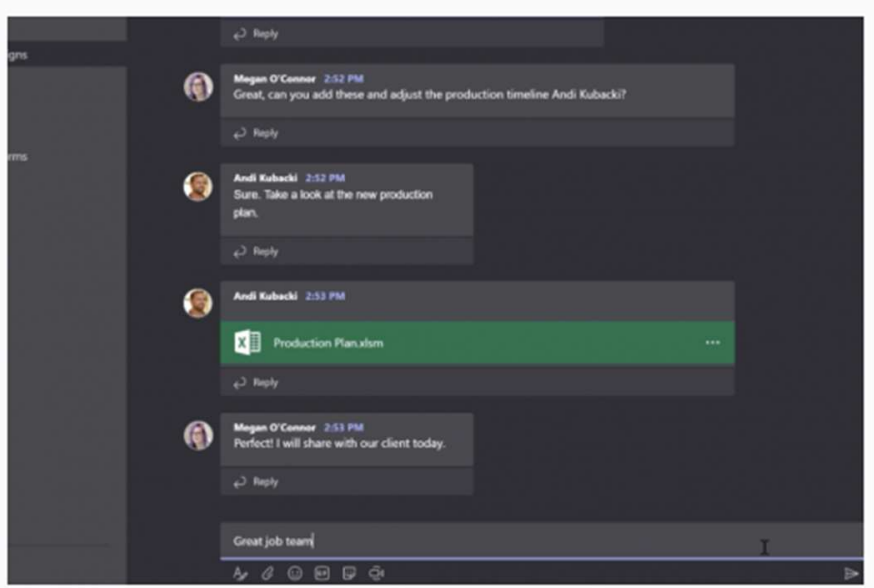


APPENDIX B - MANIPULATIONS OF EXPERIMENT 2

\author{
Information about the company \\ Apple
}

Apple Inc. designs, manufactures and markets mobile communication and media devices, personal computers and portable digital music players. The Company sells a range of related software, services, accessories, networking solutions and third-party digital content and applications. The Company's segments include the Americas, Europe, Greater China, Japan and Rest of Asia Pacific. The Company sells and delivers digital content and applications through the iTunes Store, App Store, Mac App Store, television APP Store, iBooks Store and Apple Music (collectively Internet Services).

\title{
Apple responds to natural disasters: Over $\$ 13$ Million Raised for Relief and Recovery Efforts
}

In the wake of natural disasters affecting millions of people in the US, Mexico and the Caribbean, Apple employees and customers are coming together to support relief and recovery efforts. Since Hurricane Harvey made landfall in Texas, Irma swept across the Florida Keys and along the Gulf Coast, earthquakes struck Mexico and most recently in response to Hurricane Maria's devastation throughout Puerto Rico, the Apple community has generated more than $\mathbf{\$ 1 3}$ million to help provide shelter, food, clean water and other emergency services in these communities.
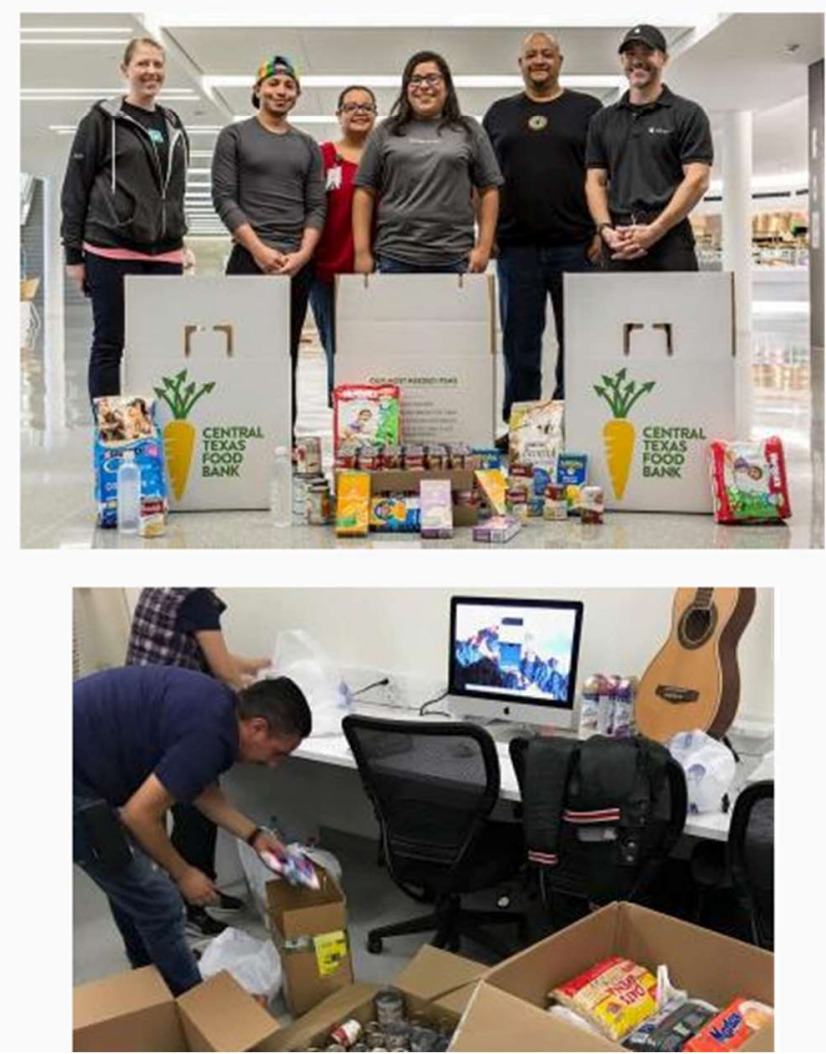